\title{
Effect of Nanoparticles Addition on the Microstructure and Properties of Lead-Free Solders: A Review
}

\author{
Peng Zhang ${ }^{1}$, Songbai Xue ${ }^{1, * \mathbb{D}}$, Jianhao Wang ${ }^{1}{ }^{\mathbb{D}}$, Peng Xue ${ }^{2}$, Sujuan Zhong ${ }^{3}$ \\ and Weimin Long ${ }^{3}$ \\ 1 College of Materials Science and Technology, Nanjing University of Aeronautics and Astronautics, Nanjing \\ 210016, China; mstzhangpeng@nuaa.edu.cn (P.Z.); wangjh@nuaa.edu.cn (J.W.) \\ 2 School of Materials Science and Engineering, Nanjing University of Science and Technology, Nanjing 210096, \\ China; xuepeng@njust.edu.cn \\ 3 State Key Laboratory of Advanced Brazing Filler Metals and Technology, Zhengzhou Research Institute of \\ Mechanical Engineering Co., Ltd., Zhengzhou 450002, China; zhongsj@zrime.com.cn (S.Z.); \\ brazelong@163.com (W.L.) \\ * Correspondence: xuesb@nuaa.edu.cn; Tel.: +86-025-8489-6070
}

Received: 12 April 2019; Accepted: 13 May 2019; Published: 17 May 2019

\begin{abstract}
With the development of microelectronic packaging and increasingly specific service environment of solder joints, much stricter requirements have been placed on the properties of lead-free solders. On account of small size effect and high surface energy, nanoparticles have been widely used to improve the microstructure and properties of lead-free solders. Therefore, the composite solders bearing nanoparticles have recently attracted wide attention. This article reviewed the recent research on $\mathrm{SnAgCu}, \mathrm{SnBi}$, and $\mathrm{SnZn}$ composite solder alloys and introduced the effect of nanoparticles on their microstructure, mechanical properties, wettability, and reliability. The mechanism of nanoparticles strengthening was analyzed and summarized. In addition, the shortcomings and future development trends of nanoparticle-reinforced lead-free solders were discussed, which is expected to provide some theoretical reference for the application of these composite solder in 3D IC package.
\end{abstract}

Keywords: nanoparticle; composite lead-free solder; microstructure; mechanical properties; wettability; reliability

\section{Introduction}

Under the drive of device miniaturization, high-density packaging technologies, such as ball grid array (BGA), chip scale package (CSP), and wafer level packaging (WLP), have been applied in the advanced electronical equipment, which decreases the joint size and calls for excellent property of packaging materials [1]. To meet the actual requirement of electronic industries, packaging materials for electronic devices are required to have not only perfect electrical conductivity, wettability, and mechanical properties, but also low cost and high reliability. Traditional $\mathrm{SnPb}$ solders were widely used in electronic packaging because of low cost and excellent performance. However, due to the toxicity of lead, most countries have implemented a series of laws such as waste electrical and electronic equipment (WEEE) and restriction of hazardous substances (RoHS), to restrict the use of lead in various electronic and electrical products [2].

Electrically conductive adhesives (ECAs) and lead-free solders were considered as promising alternatives of $\mathrm{SnPb}$ solders. ECAs, mainly composed of matrix polymer and conductive fillers, offer numerous advantages such as environmental friendliness, lower processing temperature, and fine pitch capability [3]. However, the application of ECAs is limited due to its lower thermal conductivity 
and electrical conductivity, poor mechanical properties, and low reliability [4]. Especially, ECAs can hardly meet the requirements of three-dimension integrated circuits (3D ICs) packaging technology, which easily produces high current density and Joule heating. Therefore, compared with ECAs, the development of lead-free solder alloys with better reliability, thermal, and electrical properties to replace $\mathrm{SnPb}$ solders has always been one of research focuses in the field of microelectronic joining. Although the application of $\mathrm{SnPb}$ solder is limited, its excellent performance makes it a reference standard for the development of new lead-free solders [5]. Nowadays, several Sn-based lead-free solder alloys have been synthesized, such as $\mathrm{SnAgCu}, \mathrm{SnZn}$, and $\mathrm{SnBi}$ solder alloys. However, these lead-free solders still have some shortages such as high melting point, poor wettability and reliability, and high cost, which fail to meet the actual production needs. As a result, it is urgent that an effective way to improve the performance of the solder alloys is found.

Currently, researchers mainly improve the performance of lead-free solders by microalloying and nanoparticles strengthening. Microalloying is a method of improving the properties of the solder by adding trace alloying elements to change the solder composition. The alloying elements can be mainly divided into rare earth (RE) elements ( $\mathrm{Ce}, \mathrm{La}, \mathrm{Pr}, \mathrm{Nd}$, etc.) [6,7] and other metal elements ( $\mathrm{Ga}, \mathrm{In}, \mathrm{Mg}$, $\mathrm{Ni}, \mathrm{Ag}$, etc.) [8-11]. However, there are still some shortcomings in this method, which limits the widely application of the lead-free solders containing minor alloying elements. For example, adding excessive RE elements will result in the formation of Sn whisker on the surface of solder joints, causing premature failure of electronic device [12,13].

Due to excellent physicochemical properties and size effects, nanoparticles play a significant role in refining grains, increasing mechanical properties, and improving wettability of lead-free solder [14-19]. Therefore, more and more researchers are focused on the preparation and performance characterization of the composite solders reinforced by various nanoparticles. Up to now, types of nanoparticles studied extensively mainly includes metals $\left(\mathrm{Cu}, \mathrm{Ni}, \mathrm{Mn}, \mathrm{Co}\right.$, etc.), oxides $\left(\mathrm{La}_{2} \mathrm{O}_{3}, \mathrm{Fe}_{2} \mathrm{O}_{3}\right.$, $\mathrm{TiO}_{2}$, etc.), ceramic ( $\mathrm{SiC}, \mathrm{TiC}$, etc.), and carbon materials (carbon nanotubes (CNTs), graphene nanosheets (GNSs), etc.).

Although some research results have been achieved, there are still some deficiencies in the strengthening effect of nanoparticles. For example, the effect of nanoparticles on the melting characteristics of lead-free solder is not obvious [20-22]. Besides, there is no practical application of the composite solders reinforced by nanoparticles in electronic industries because of its high cost and complex preparation. Therefore, in order to comply with the trend of green development and meet the requirements of the electronics industry for packaging materials, the influence of nanoparticles doping on the microstructure and properties of lead-free solders was analyzed comprehensively, which is expected to provide some theoretical reference for the development of high-performance nanoparticle-reinforced lead-free solders.

\section{SnAgCu-Based Solders}

\subsection{Microstructure}

Adding trace $\mathrm{La}_{2} \mathrm{O}_{3}$ nanoparticles to SAC-305 solder could provide a large number of nucleation sites to refine the microstructure of the composite solder. However, when the content exceeded $0.1 \mathrm{wt} . \%$, the nanoparticles would aggregate together, resulting in the formation of cracks and voids, as shown in Figure 1 [23].

In the reflow process, a brittle interfacial layer is rapidly formed at the interface between the molten solder and the substrate; meanwhile, the overgrowth of intermetallic compounds (IMCs) will result in lower connecting strength of solder joints [24,25]. After multiple reflow, the coarsening of the $\mathrm{Cu}_{6} \mathrm{Sn}_{5}$ layer occurs and the $\mathrm{Cu}_{3} \mathrm{Sn}$ layer is formed at the interface between the $\mathrm{Cu}_{6} \mathrm{Sn}_{5}$ layer and the substrate, which decreases the reliability of the joints. Chan et al. [26] found that adding $\mathrm{Zn}$ nanoparticles could decrease the growth rate of $\mathrm{Cu}_{6} \mathrm{Sn}_{5}$ and suppress the formation of $\mathrm{Cu}_{3} \mathrm{Sn}$. Research [27] found that the grain size of $\mathrm{Cu}_{6} \mathrm{Sn}_{5}$ IMC increased with the increasing reflow time, and 
$\mathrm{TiO}_{2}$ nanoparticles could effectively suppress the growth of the IMC layer by preventing the diffusion of $\mathrm{Cu}$ and $\mathrm{Sn}$ atoms.

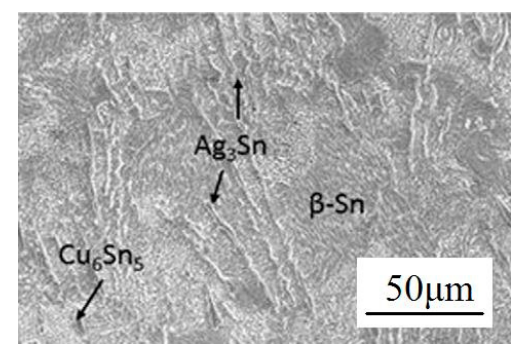

(a)

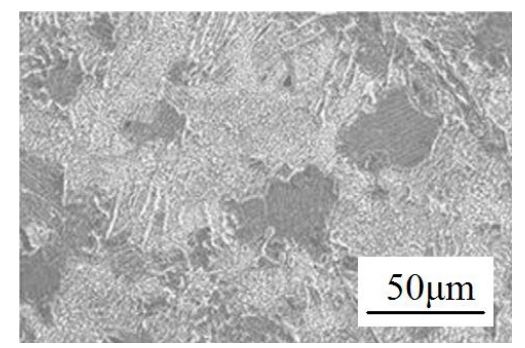

(c)

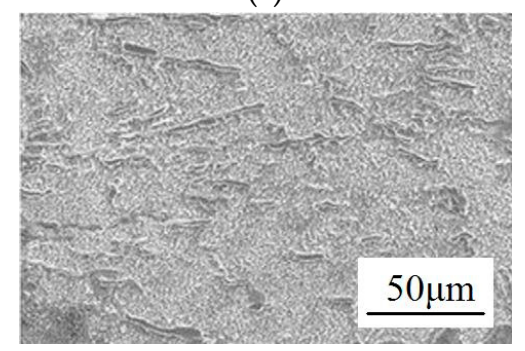

(e)

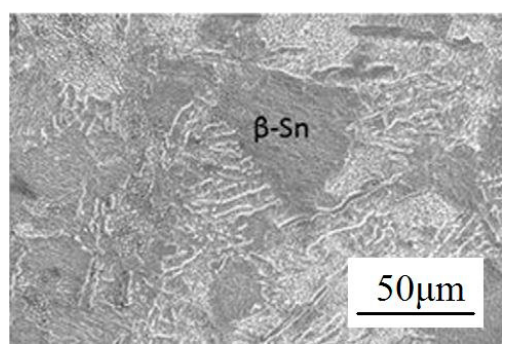

(b)

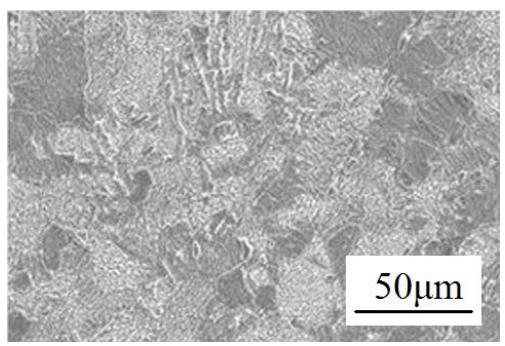

(d)

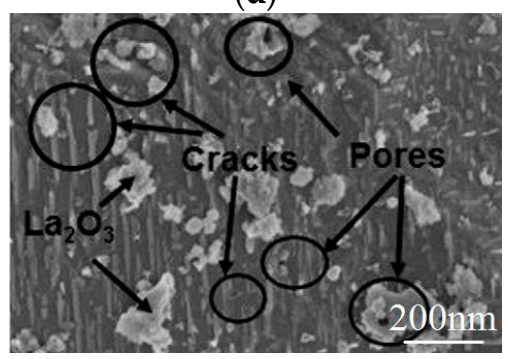

(f)

Figure 1. Field emission scanning electron microscope (FESEM) image of SnAgCu-nano $\mathrm{La}_{2} \mathrm{O}_{3}$ composite solder: (a) $0 \% \mathrm{La}_{2} \mathrm{O}_{3}$; (b) $0.01 \% \mathrm{La}_{2} \mathrm{O}_{3}$; (c) $0.03 \% \mathrm{La}_{2} \mathrm{O}_{3}$; (d) $0.05 \% \mathrm{La}_{2} \mathrm{O}_{3} ;$ (e) $0.1 \% \mathrm{La}_{2} \mathrm{O}_{3}$; (f) high-resolution image of (e) [23].

Considering the effect of secondary phase particles on the migration of grain boundary during grain growth, the total restraining force acting on the boundary can be expressed as follows:

$$
\mathrm{F}=\frac{3 f \gamma_{b}}{2 r}
$$

where $f$ is the volume fraction of secondary phase particles at grain boundary, $\gamma_{b}$ is the interface energy per unit area of grain boundary, and the $r$ is the radius of secondary phase particles. It is obvious that $\mathrm{F}$ is inversely proportional to $r$. Therefore, the $\gamma-\mathrm{Fe}_{2} \mathrm{O}_{3}$ nanoparticle with smaller size have a better refining effect on $\beta$-Sn phase in SAC105- $\mathrm{Fe}_{2} \mathrm{O}_{3}$ composite solder, as shown in Figure 2 [28]. On account of high surface energy, the doped CNTs were easily adsorbed on the surface of $\beta$-Sn and IMCs, which significantly refined the microstructure of the composite solder by inhibiting the migration of grain boundaries [29]. 


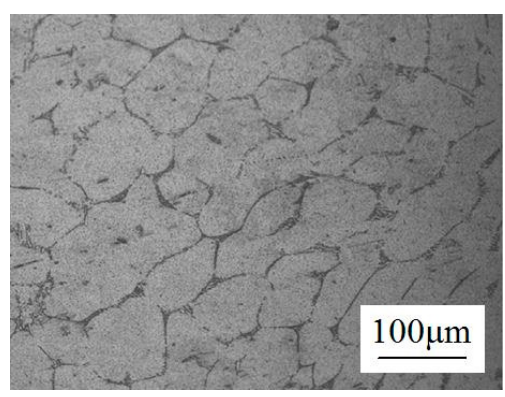

(a)

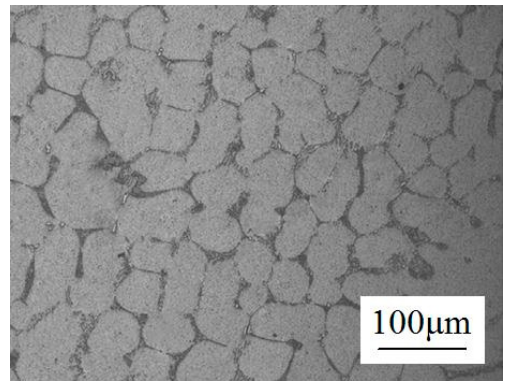

(c)

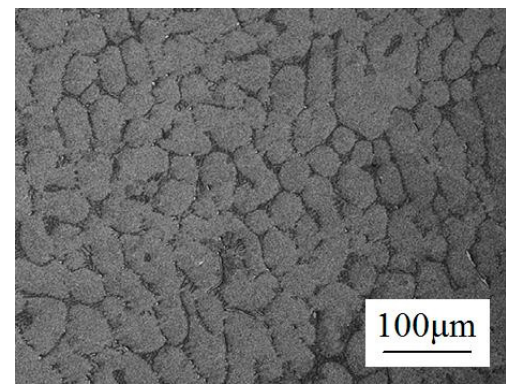

(b)

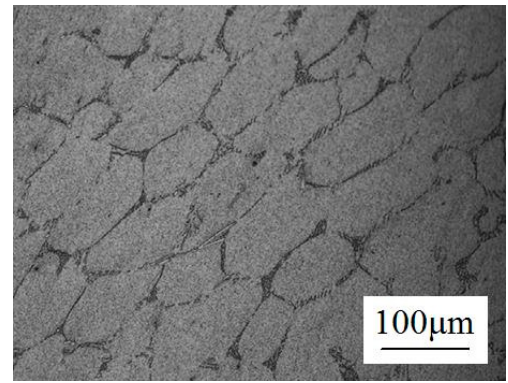

(d)

Figure 2. Microstructure of the solders: (a) SAC105; (b) SAC105-nano $\mathrm{Fe}_{2} \mathrm{O}_{3}$ (20 nm); (c) SAC105-nano $\mathrm{Fe}_{2} \mathrm{O}_{3}(50 \mathrm{~nm}) ;$ (d) SAC105-nano $\mathrm{Fe}_{2} \mathrm{O}_{3}$ (200 nm) [28].

\subsection{Mechanical Properties}

During operation, solder joints are subjected to the thermal-mechanical stress because of the temperature change and mismatch in the CTEs (coefficients of thermal expansion) of different materials. Therefore, high enough strength is required for the joints due to the accumulation of residual stress during operation caused by CETs mismatch [29]. The addition of minor Al nanoparticles into the $\mathrm{SnAgCu}$ solder could obviously refine $\mathrm{Cu}_{6} \mathrm{Sn}_{5}, \mathrm{Ag}_{3} \mathrm{Sn}$ IMCs, and eutectic microstructure, thus enhancing the mechanical properties of the solder. However, the mechanical properties of the solder would decrease once the content of $\mathrm{Al}$ nanoparticles exceeded $0.1 \mathrm{wt} . \%$, as shown in Figure 3 [30]. Tang [31] found the fracture of some $\mathrm{Sn} 0.3 \mathrm{Ag} 0.7 \mathrm{Cu}$ as flowed solder joints presented brittle characteristic and some microcracks occurred. Owing to the growth of IMCs during reflow, a large stress was accumulated inside or around the IMC, which would result in local stress concentration and strength reduction in the tensile test. Since Mn nanoparticles addition could reduce the IMC thickness and reduce the accumulation of stress during reflow, the UTS of Mn-containing solder joints was improved.

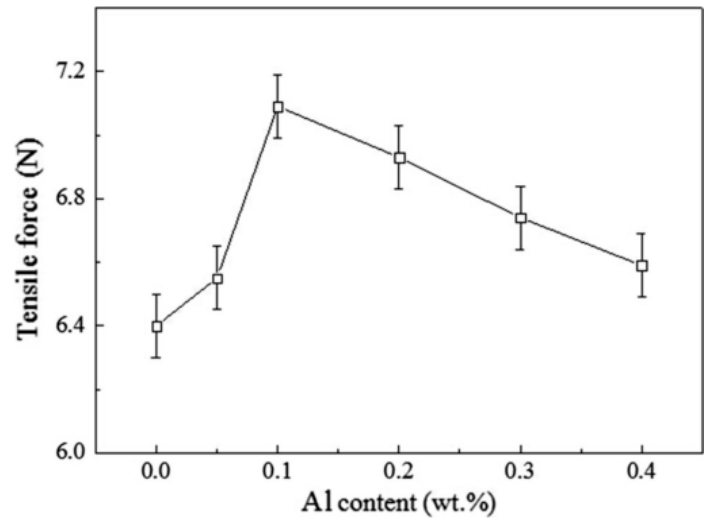

(a)

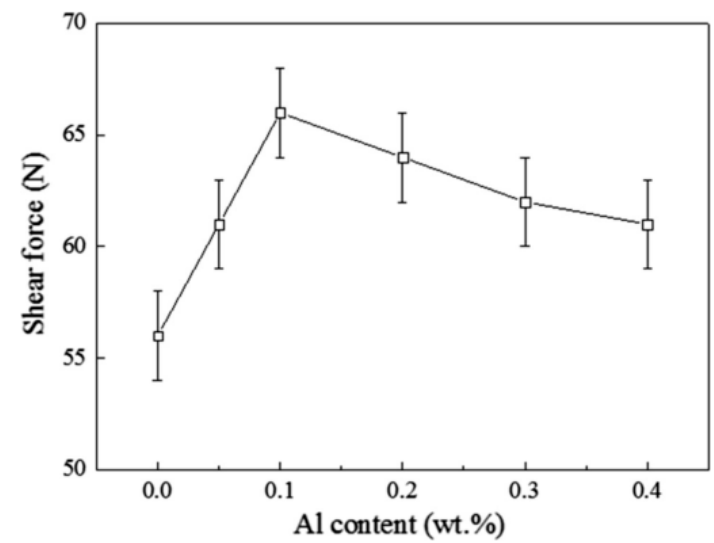

(b)

Figure 3. The mechanical properties of SAC105-xAl solder joints: (a) Tensile force; (b) shear force [30]. 
Compared with the original solder, the strength and hardness of the $\mathrm{SnAgCu}$-nano $\mathrm{TiO}_{2}$ composite solder were significantly improved because $\mathrm{TiO}_{2}$ particles could pin the movement of dislocations and grain boundaries. However, it is worth noting that the plasticity of the composite solder decreased to a certain extent and many holes were found at the $\mathrm{Ag}_{3} \mathrm{Sn}$ grain boundaries $[32,33]$. The mechanical properties of $\mathrm{SnAgCu}$-nano $\mathrm{La}_{2} \mathrm{O}_{3}$ composite solder were greatly improved because the addition of $\mathrm{La}_{2} \mathrm{O}_{3}$ nanoparticles refined the microstructure and increased dislocation density by secondary phase strengthening [23].

Ag-GNSs nanoparticles were added into $\mathrm{SnAgCu}$ solder and the research result shows that compared with GNSs nanoparticles, the strengthening effect of Ag-GNSs nanoparticles is more obvious because Ag can react with Sn matrix to form Ag3Sn, which makes the distribution of Ag-GNSs in the matrix more uniform and stable [34].

\subsection{Wettability}

Due to the high melting point, Ni nanoparticles addition can form a frame construction in the solder joint, thereby promoting the spreading of the molten $\mathrm{SnAgCu}$ solder [35,36]. During the wetting process, Ag nanoparticles in the composite flux gathered at the interface between the molten $\mathrm{SnAgCu}$ solder and the $\mathrm{Cu}$ substrate, reducing the surface energy of the system and greatly increasing the wetting force [37].

Absorption of $\mathrm{Fe}_{2} \mathrm{O}_{3}$ nanoparticles on the surface of the $\mathrm{Cu}$ substrate decreased the surface tension of molten $\mathrm{SnAgCu}$-nano $\mathrm{Fe}_{2} \mathrm{O}_{3}$ composite solder and thus the wettability of the solder was improved [38]. Figure 4 shows the effect of $\alpha-\mathrm{Al}_{2} \mathrm{O}_{3}$ nanoparticles on the spreading area of $\mathrm{Sn}-0.3 \mathrm{Ag}-0.7 \mathrm{Cu}$ solder; the maximum spreading area of the composite solder is $79 \mathrm{~mm}^{2}$ with $0.12 \mathrm{wt} . \%$ $\mathrm{Al}_{2} \mathrm{O}_{3}$ nanoparticles addition [39]. The wettability of the composite solder increases because $\alpha-\mathrm{Al}_{2} \mathrm{O}_{3}$ nanoparticles are easily adsorbed at the surface of $\mathrm{Cu}$ substrate and decrease the surface tension of the solder. According to the Young equation, the contact angle increases when the surface tension is reduced, resulting in a bigger spreading area; the schematic diagrams of the wetting and spreading process is shown in Figure 5.

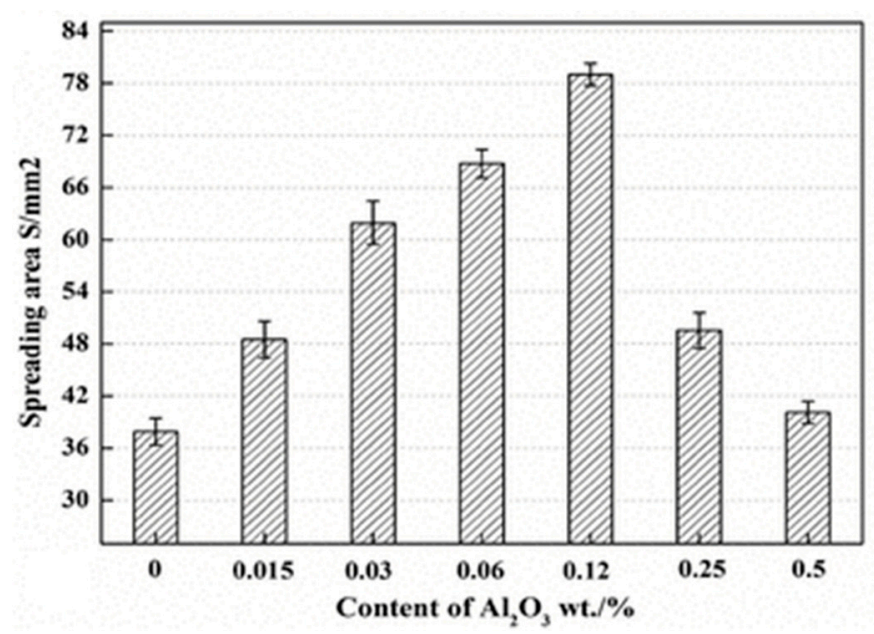

Figure 4. Spreading areas of $\mathrm{SnAgCu}-\mathrm{nano} \mathrm{Al}_{2} \mathrm{O}_{3}$ composite solder [39].

Appropriate content of GNSs can significantly increase the spreading area of SnAgCu solder; however, when the content exceeds $0.1 \mathrm{wt} . \%$, GNSs tend to agglomerate and float onto the top of the molten solder and, hence, the wettability of the composite solder decreases [40]. 


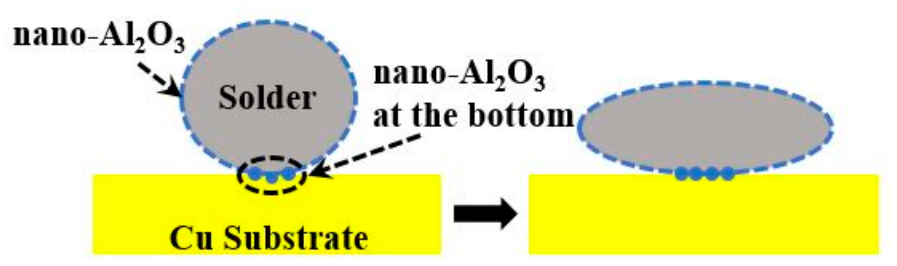

(a)

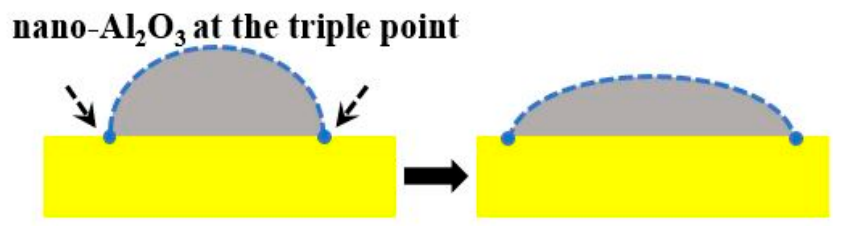

(b)

Figure 5. Schematic diagram of the effect of $\mathrm{Al}_{2} \mathrm{O}_{3}$ nanoparticles on the wetting and spreading: (a) Contribution to wetting; (b) contribution to spreading [39].

\subsection{Reliability}

After high-temperature storage, the coarsening IMC layer of solders joint could be obtained, which has been proven to be harmful to solder joints [41-43]. Competitive growth of $\mathrm{Cu}_{6} \mathrm{Sn}_{5}$ and $\mathrm{Cu}_{3} \mathrm{Sn}$ layers reduces the mechanical properties of solder joints and increases the risk of fracture [44]. Zhao et al. [45] found the absorption of $\mathrm{TiO}_{2}$ nanoparticles on the surface of interfacial IMCs could hinder the diffusion and reaction between $\mathrm{Cu}$ and $\mathrm{Sn}$, so the formation and growth of IMCs was inhibited. With $0.5 \mathrm{wt} . \% \mathrm{TiO}_{2}$ nanoparticles addition, the activation energies of overall IMC layer growth increased from $42.48 \mathrm{KJ} / \mathrm{mol}$ to $60.31 \mathrm{KJ} / \mathrm{mol}$, which meant more energy was needed for elements diffusion and IMCs growth [46]. TiC nanoparticles can also lower the growth rate of IMCs layer during aging. One reason is that the particles can be adsorbed on the surface of IMCs and the other is that the gathering of TiC particles at the interface decreases the concentration gradient of $\mathrm{Sn}$. Consequently, appropriate content of $\mathrm{TiC}$ nanoparticles effectively inhibited the growth of $\mathrm{Cu}_{6} \mathrm{Sn}_{5}$ and $\mathrm{Cu}_{3} \mathrm{Sn}$ layers during aging, as shown in Figure 6 [47].

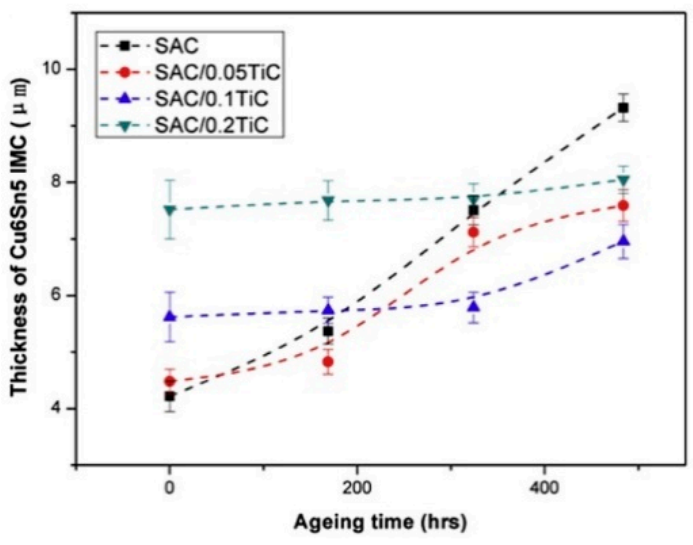

(a)

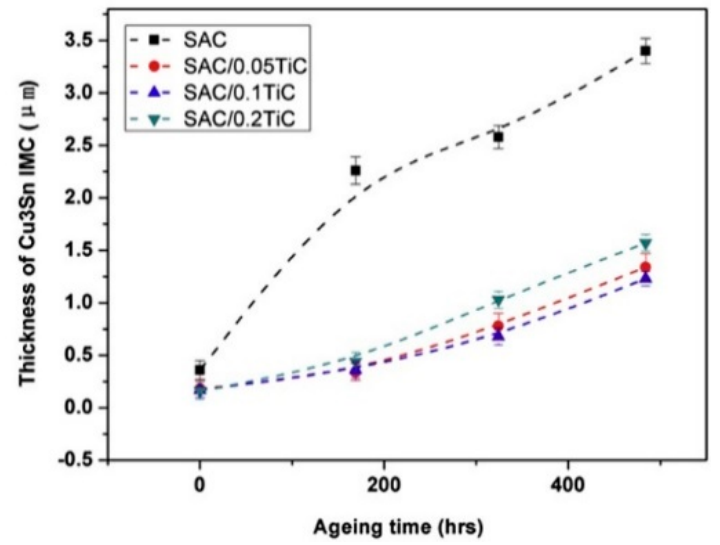

(b)

Figure 6. Effect of TiC nanoparticles content on the thickness of IMCs layers during aging (a) $\mathrm{Cu}_{6} \mathrm{Sn}_{5}$; (b) $\mathrm{Cu}_{3} \mathrm{Sn}[47]$.

The increasing current density in IC brings a deteriorative electromigration effect and the improvement of EM resistance of solder joints gradually becomes a research focus in reliability research $[48,49]$. CNTs will entangle with each other after adding it in the strengthening phase in lead-free solder. Because of the excellent electrical conductivity of CNTs, the conductivity channel formed by CNTs greatly decreases the current intensity of the solder matrix, which increases the service 
life of the solder joints $[29,50,51]$. After SAC-CNTs/Cu solder joints underwent aging at $100{ }^{\circ} \mathrm{C}$ and a current density of $1.2 \times 10^{4} \mathrm{~A} / \mathrm{cm}^{2}$ for $336 \mathrm{~h}$, a $\mathrm{Cu}_{3} \mathrm{Sn}$ layer formed between the $\mathrm{Cu}_{6} \mathrm{Sn}_{5}$ layer and the $\mathrm{Cu}$ substrate. The diffusion of $\mathrm{Cu}$ atoms from the solder matrix to the interface was impeded due to the pinning effect of $\mathrm{CNTs}$, therefore the thickness of $\mathrm{Cu}_{6} \mathrm{Sn}_{5}$ and $\mathrm{Cu}_{3} \mathrm{Sn}$ layers at both the anode side and cathode side decreased with the increase of CNTs content [52].

Since lead-free solders are usually exposed to corrosion environments, it is important to improve corrosion resistance of the solder for improving reliability and mechanical properties of solder joints [53]. Han [54] found that GNSs could significantly improve corrosion resistance of SAC solder and the optimum content was $0.03 \mathrm{wt} . \%$. Uniformly distributed GNSs increased the tortuosity of oxygen diffusion pathway and inhibited the diffusion of oxygen in the solder, as illustrated in Figure 7. Furthermore, the addition of GNSs refined the microstructure of the solder and the fine grains formed the initial passivation film to inhibit further corrosion.

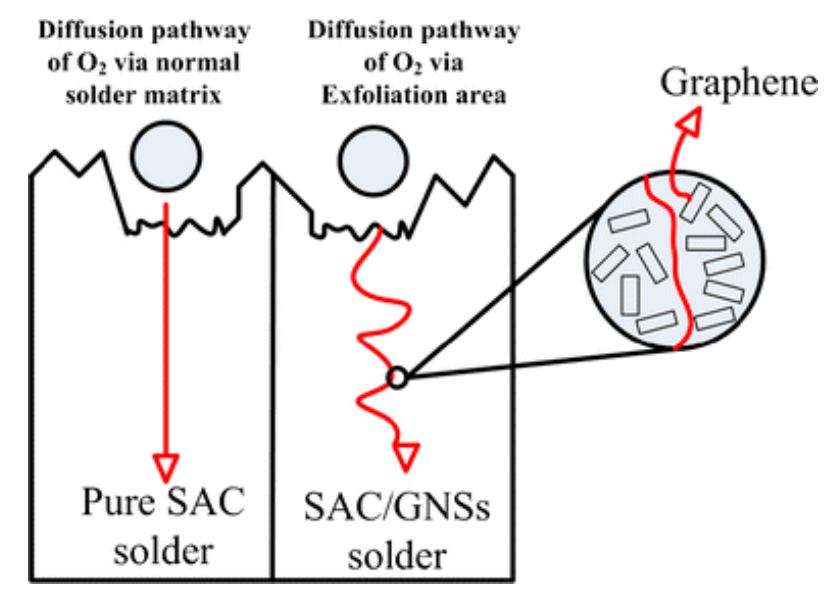

Figure 7. Schematic representation of the inhibition effect of graphene nanosheets (GNSs) on oxygen diffusion [54].

\section{SnBi-Based Solders}

\subsection{Microstructure}

After adding Ni nanoparticles into SnBiAg solder, the Bi-rich phase and $\mathrm{Ag}_{3} \mathrm{Sn}$ IMC was refined because the formation of Ni-Sn IMCs could act as nucleation sites and inhibit the grain growth [55]. With the addition of $0.4 \mathrm{wt} . \% \mathrm{Ag}$ nanoparticles, a mass of dispersed nano- $\mathrm{Ag}_{3} \mathrm{Sn}$ particles formed, which inhibited the grain growth and provided a refined microstructure [56]. It is worth noting that refinement effect does not always increase with the decrease of nanoparticles dimension. Because of small size and high surface energy, Ag nanoparticles with a size of $31 \mathrm{~nm}$ have a stronger tendency to agglomerate to larger particles and cannot disperse in the solder matrix in comparison with those of $76 \mathrm{~nm}$ and $133 \mathrm{~nm}$ [57]. As a result, SnBi solder-doped $31 \mathrm{~nm}$ Ag nanoparticles presents larger grain size and interphase spacing, as shown in Figure 8.

Liu et al. [58] has reported the influence of $\mathrm{Cu}$ nanoparticles on the microstructure of SnBi nano-composite solder. The formation of $\mathrm{Cu}_{6} \mathrm{Sn}_{5}$ IMC phase was detected by analyzing XRD patterns of $\mathrm{SnBi}-3 \mathrm{Cu}$ solder. During solidification, the $\mathrm{Cu}_{6} \mathrm{Sn}_{5}$ nanoparticles served as nucleation sites and greatly increased the nucleation rate, which led to the grain refinement of the solder bulk. Wu et al. [59] found that with $0.05 \mathrm{wt} . \% \mathrm{Cu}_{6} \mathrm{Sn}_{5}$ nanoparticles addition, the grain refinement of SnBi-nano $\mathrm{Cu}_{6} \mathrm{Sn}_{5}$ composite solder reached the maximum. Smaller amount of $\mathrm{Cu}_{6} \mathrm{Sn}_{5}$ nanoparticles had no obvious effect on the nucleation rate, however when the content was excessive, the agglomeration of $\mathrm{Cu}_{6} \mathrm{Sn}_{5}$ nanoparticles would weaken its refinement effect. 


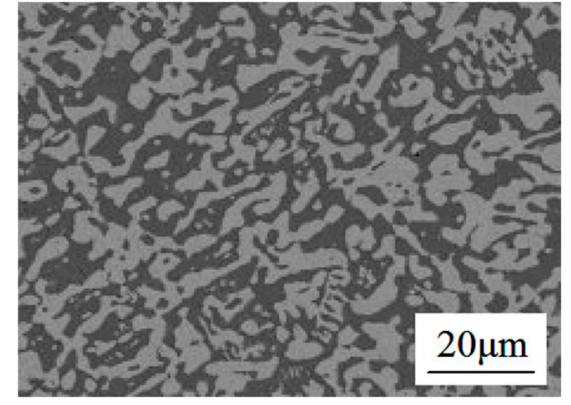

(a)

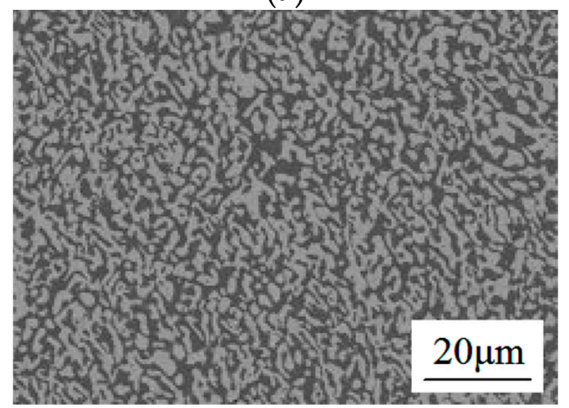

(c)

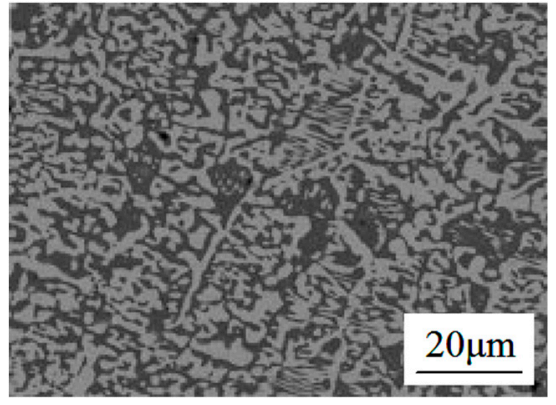

(b)

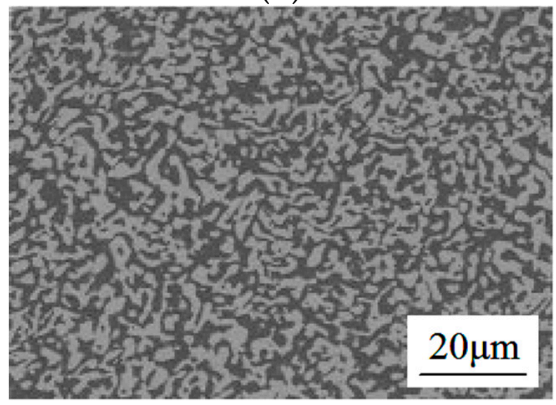

(d)

Figure 8. SEM morphology of as-prepared solder: (a) Pure SnBi solder; (b) SnBi solder-doped $31 \mathrm{~nm}$ Ag nanoparticles; (c) SnBi solder-doped $76 \mathrm{~nm}$ Ag nanoparticles; (d) SnBi solder-doped $133 \mathrm{~nm} \mathrm{Ag}$ nanoparticles [57].

$\mathrm{Ni}$ can react with $\mathrm{SnBi}$ solder matrix to form some stable intermetallic compounds such as $\mathrm{Ni}_{3} \mathrm{Sn}_{4}$ and $\mathrm{Ni}_{3} \mathrm{Sn}$, thereby increasing the bonding force between Ni-CNTs and the matrix. As a result, Ni-CNTs distribute more uniformly and become harder to agglomerate in comparison with pure CNTs [60,61]. Therefore, Ni-CNTs can effectively suppress the growth of interfacial IMCs because of their higher stability in the solder joints during soldering.

\subsection{Mechanical Properties}

The formation of IMCs layer is the basis of fine bonding between the solder and substrate, but the excessive growth of IMCs layer will reduce the reliability of interconnection and the lifetime of electronic devices. Research [57] found Ag nanoparticles addition could suppress the growth of Cu-Sn IMC and improve the shear strength of the solder joints by $18.9 \%$ after 180 min liquid reaction at $220^{\circ} \mathrm{C}$. The improvement behavior can be explained by refinement strengthening, dispersion strengthening, and absorption theory. Under external force, the deformation of the composite solder is dispersed to smaller grains with different orientation, which suppressed the formation of cracks and increased the ductility of the solder.

$\mathrm{Wu}$ et al. [62] reported that $0.05 \mathrm{wt}$.\% Ni-CNTs could effectively increase the ultimate tensile strength (UTS) of SnBi solder bulks and joints, as shown in Figure 9. What is more, the fracture surface of SnBi-CNTs solder appeared more regular than the plain SnBi solder and CNTs were detected pining at the grain boundaries in high magnification, which demonstrated that the grain growth was suppressed, and the microstructure was refined by Ni-CNTs addition. However, excessive CNTs could gradually translate the fracture modes from ductile fracture to brittle fracture and decrease the UTS and elongation of the composite solder at the same time. 


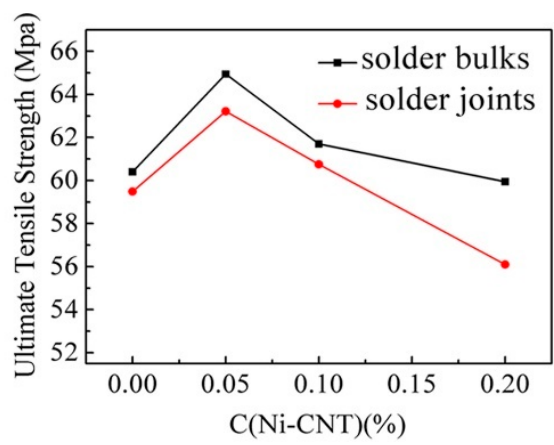

(a)

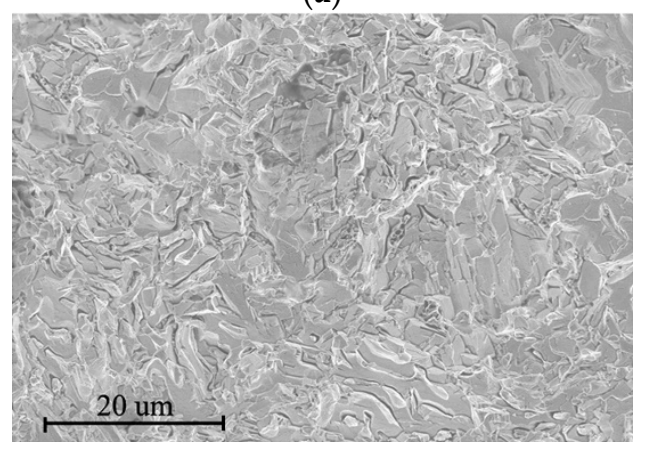

(c)

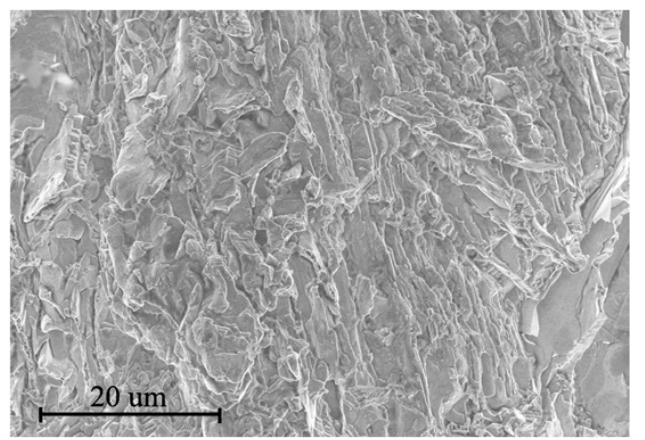

(e)

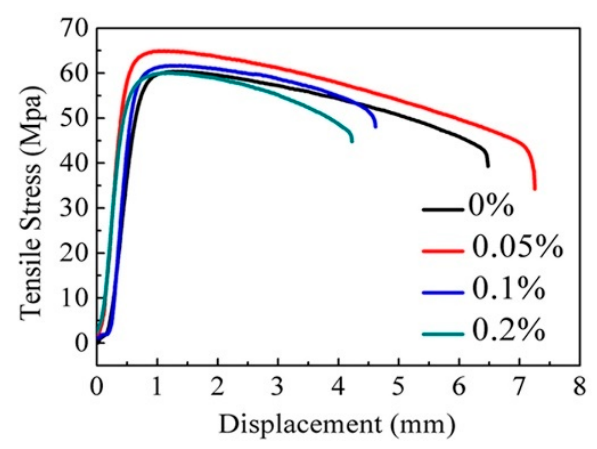

(b)

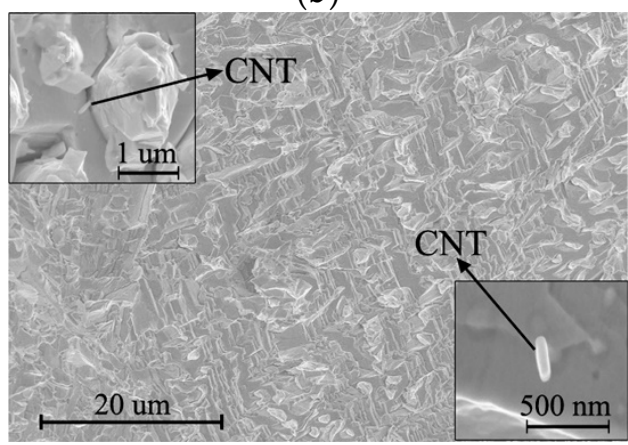

(d)

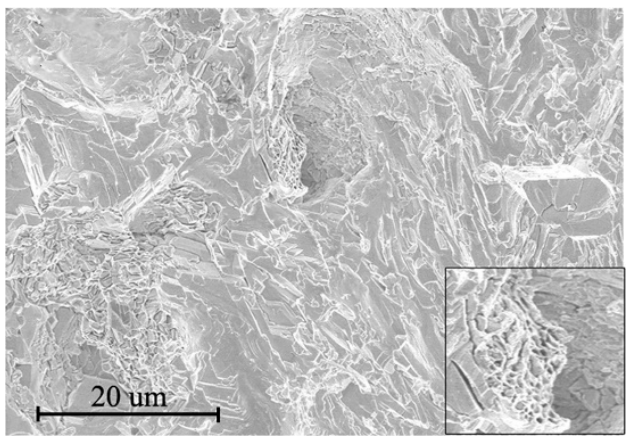

$(\mathbf{f})$

Figure 9. Effect of carbon nanotubes (CNT) on the tensile properties of SnBi solder: (a) ultimate tensile strength (UTS) of SnBi-xCNT solder bulks and solder joints; (b) tensile stress-displacement curves of the SnBi-xCNT solder bulks $(x=0,0.05,0.1,0.2) ;(\mathbf{c}-\mathbf{f})$ fracture surfaces of the SnBi-xCNT solder slab $(x=0,0.05,0.1,0.2)[62]$.

It was found that the effect of GNSs on the fracture surface of SnBi solder was similar to that of CNTs [63]. The phenomenon that GNSs embedded in the fractured solder bulk was investigated, meaning strong bonding was formed between GNSs and the matrix. When the solder was under tensile stress, GNSs would be pulled out from the matrix to reduce the stress concentration that appeared in the crack tip. However, due to the restacking behavior of GNSs, the elongation of the composite solders decreased when the content exceeded $0.01 \%$. Wu et al. [64] used finite element modeling (FEM) method to analyze the stress distribution at the interface of GNSs reinforced Sn58Bi0.7Zn solder joints (after aging for $120 \mathrm{~min}$ ) in the tensile test. The result showed that the GNSs addition changed the maximum stress position from the $\mathrm{Cu} / \mathrm{IMC}$ interface in undoped joints to the IMC/solder interface in GNSs-doped joints, which indicated that the composite solder joints have better tensile properties.

\subsection{Wettability}

Adding $\mathrm{BaTiO}_{3}$ nanoparticles can reduce the surface tension between the liquid solder and increase the fluidity of the molten solder, thereby increasing the spreading coefficient of SnBi solder 
greatly [65]. Compared with original $\mathrm{SnBi}$ solder, the spread area of $\mathrm{SnBi}-1 \mathrm{Y}_{2} \mathrm{O}_{3}$ composite solder on the $\mathrm{Cu}$ substrate increased by $20 \%$ under the same experimental conditions, as shown in Figure 10 [66]. When the addition of $\mathrm{Y}_{2} \mathrm{O}_{3}$ exceeded $1 \mathrm{wt} . \%$, the increasing viscosity of the molten solder inhibited its flow and, hence, the wettability decreased.

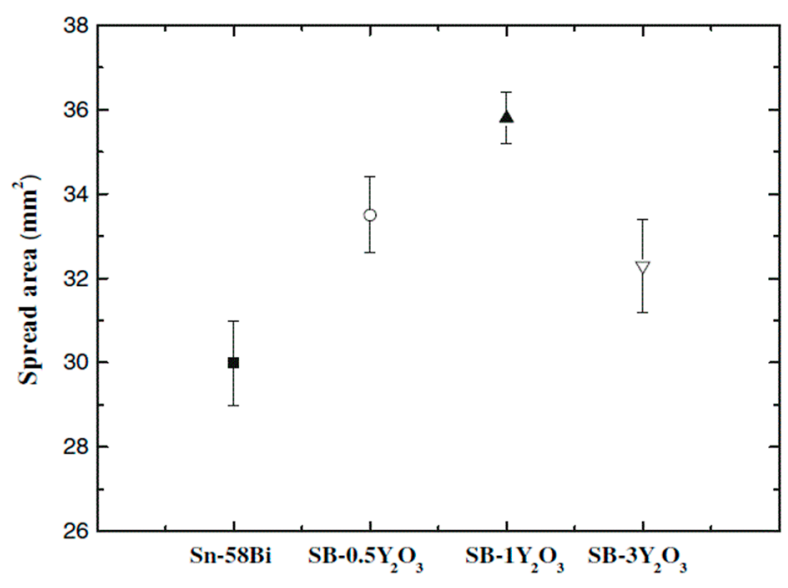

Figure 10. The effect of $\mathrm{Y}_{2} \mathrm{O}_{3}$ content on the spread area of $\mathrm{SnBi}$-nano $\mathrm{Y}_{2} \mathrm{O}_{3}$ composite solder on the Cu substrate [66].

With the addition of $0.5 \mathrm{wt} . \% \mathrm{Ni}$ nanoparticles, the contact angle of molten SnBiAg-Ni composite solder on the $\mathrm{Cu}$ substrate decreased from $33.1^{\circ}$ to $23.4^{\circ}$ [55]. Due to extremely high surface activity, $\mathrm{Ni}$ nanoparticles tended to gather at the molten $\mathrm{SnBi} / \mathrm{Cu}$ surface, which lowered the surface tension between the molten solder and the substrate and significantly promoted the spreading process. Therefore, the wettability of SnBi solder bearing Ni nanoparticles was improved.

Sun et al. [67] reported that nano-Cu particles could react with $\mathrm{Sn}$ to form stable $\mathrm{Cu}_{6} \mathrm{Sn}_{5} \mathrm{IMC}$ during reflow, which inhibited the spreading of the molten solder. Therefore, the spread ratio (SR) value of $\mathrm{SnBi}$ solder bearing $\mathrm{Cu}$ nanoparticles decreased with the increasing content of $\mathrm{Cu}$ nanoparticles.

\subsection{Reliability}

The reliability of SnBi solder joint is sensitive to the high-density current, which is much more severe in the increasingly finer pitch of advanced electronical devices [68]. Compared with other $\mathrm{Sn}$-based solders, the $\mathrm{Cu}_{6} \mathrm{Sn}_{5}$ layer at the $\mathrm{SnBi} / \mathrm{Cu}$ interface grows faster and the probability of cracks formation increases under high-density current. The current also causes the migration and segregation of Sn and Bi atoms in the solder, which results in the formation of Sn-rich layer and brittle Bi-rich layer on the anode side and cathode side, respectively [69,70]. Numerous studies have shown that adding nanoparticles can significantly improve the electromigration resistance of SnBi solders.

Chan et al. [71] reported that nano-Ag particles could react with $\mathrm{Sn}$ to form fine and dispersed $\mathrm{Ag}_{3} \mathrm{Sn}$ particles, which refined the microstructure of the composite solder and hindered the migration of Bi atoms. After adding $2 \mathrm{wt} . \%$ Ag nanoparticles, Bi atomic flux of Sn58Bi solder decreased from $7.43 \times 10^{12}$ atoms $/ \mathrm{cm}^{3}$ to $4.77 \times 10^{12}$ atoms $/ \mathrm{cm}^{3}$ under the current density of $5 \times 10^{3} \mathrm{~A} / \mathrm{cm}^{2}$ at $303 \mathrm{~K}$, which meant $\mathrm{SnBi}-\mathrm{Ag}$ solder joints have stronger $\mathrm{EM}$ resistance. Nano- $\mathrm{Al}_{2} \mathrm{O}_{3}$ particles tended to gather at the surface of interfacial IMCs layer and inhibited the atomic migration in the solder joints under the electro-thermal treatment, and thus, the EM resistance of the composite solder is significantly improved [72].

The addition of nanoparticles also has an important influence of the corrosion resistance. The corrosion rate can be calculated as:

$$
R=\frac{8.76 \times 10^{7} \times\left(M-M_{t}\right)}{S T \rho}
$$


where $M$ and $M_{t}$ represent the mass of sample before and after corrosion, $S$ is the surface area of sample, $T$ is the corrosion time, and $\rho$ is the density of sample [73]. Figure 11 [59] illustrates that $0.05 \mathrm{wt} . \%$ and $0.1 \mathrm{wt} . \% \mathrm{Cu}_{6} \mathrm{Sn}_{5}$ nanoparticles obviously suppress the growth of corrosion rate, especially in the first 10 days. The grain-refining effect of $\mathrm{Cu}_{6} \mathrm{Sn}_{5}$ nanoparticles results in more boundaries, which can serve as corrosion barriers, thus improving the corrosion resistance of the composite solder. A similar phenomenon was detected in the corrosion process of the SnBi-GNSs composite solder [63]. After corrosion of $400 \mathrm{~h}$, Bi dendrites formed and less ditches existed at the gapping space of surface microstructure with the addition of $0.05 \mathrm{wt} . \%$ GNSs. Besides, the corrosion rate of the SnBi-0.05GNSs solder almost remained stable at $0.45 \mathrm{~mm} / \mathrm{y}$.

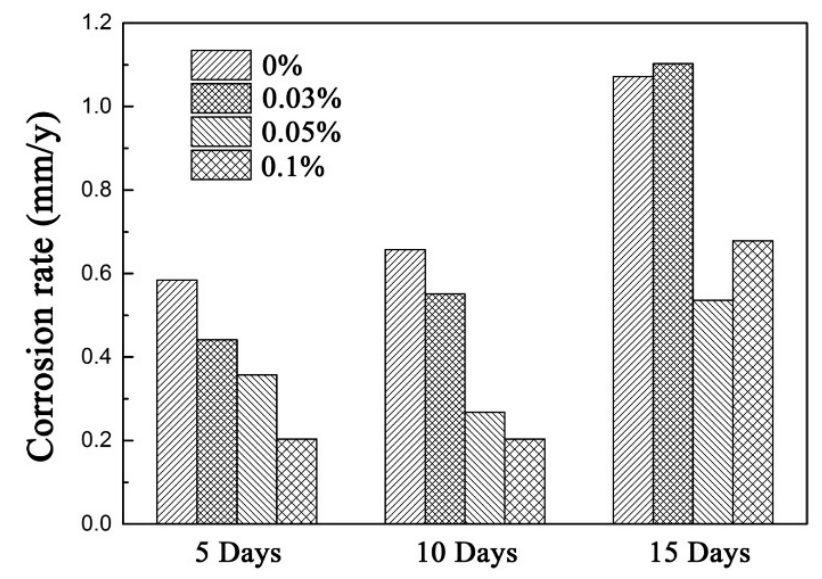

Figure 11. Corrosion rate of $\mathrm{SnBi}-\mathrm{xnano} \mathrm{Cu}_{6} \mathrm{Sn}_{5}$ composite solder: $\mathrm{x}=0 \%, 0.03 \%, 0.05 \%, 0.1 \%$ [59].

\section{SnZn-Based Solders}

\subsection{Microstructure}

The matrix microstructure of the SnZn solder mainly consists of $\beta$-Sn phase and needle-shaped $\alpha$-Zn phase, in which the coarsening $\alpha$-Zn phase greatly decreases the mechanical properties of SnZn solder [74]. Besides, the existence of $\mathrm{Zn}$-rich phase greatly reduces the oxidation resistance of the SnZn solder, which limits the practical use of the SnZn solder. Different from other Sn-based solders, the interfacial IMCs layer of the $\mathrm{SnZn} / \mathrm{Cu}$ solder joint is mainly $\mathrm{Cu}_{5} \mathrm{Zn}_{8}$, which increases the risk of fracture of solder joints during service due to its poor reliability [75].

It is generally known that soldering process parameters have a great influence on the microstructure and properties of solder joints. Zhang et al. [76] found the thickness of $\mathrm{Cu}_{5} \mathrm{Zn}_{8}$ layer increased with the reflow time and temperature, and the addition of $\mathrm{Ni}$ and $\mathrm{Ag}$ nanoparticles could effectively suppress the IMC growth behavior. Besides, with the addition of Ni nanoparticles, the grain growth of needle-shaped $\alpha$-Zn phase could also be inhibited because Zn-Ni IMCs and Ni nanoparticles increased the heterogeneous nucleation sites, as shown in Figure 12 [77]. Due to high surface energy and large special surface area, $\mathrm{Al}_{2} \mathrm{O}_{3}$ nanoparticles can also provide nucleation sites during the solidification process of the solder. So, it can not only inhibit the coarsening of dendrite Sn- $\mathrm{Zn}$ eutectic structure, but also refine the microstructure of the composite solder [78].

The gathering of $\mathrm{ZrO}_{2}$ nanoparticles at the phase boundaries decreased surface energy of the boundaries and inhibited the growth of $\mathrm{Zn}$-rich phase [79]. Therefore, the average grain size and spacing of $\mathrm{Zn}$-rich phase were significantly reduced by the addition of $\mathrm{ZrO}_{2}$ nanoparticles, as shown in Table 1. It was also reported that the addition of $\mathrm{ZrO}_{2}$ changed the thickness and composition of interfacial IMCs in $\mathrm{SnZn}-\mathrm{ZrO}_{2} / \mathrm{Cu}$ solder joints. Due to the refining effect of $\mathrm{ZrO}_{2}$ nanoparticles, less $\mathrm{Zn}$ atoms could migrate from the solder bulk to the interface to form $\mathrm{Cu}_{5} \mathrm{Zn}_{8}$ layer while the migration of $\mathrm{Cu}$ atoms became easier, resulting in the increased thickness of $\mathrm{Cu}_{6} \mathrm{Sn}_{5}$ layer. A small addition of 
$\mathrm{ZnO}$ nanoparticles can significantly decrease the sizes of the $\beta$-Sn dendrites [80]. The refinement can be attributed to the absorption of $\mathrm{ZnO}$ on the grain surface, which reduces the growth rate of $\beta$-Sn grains.

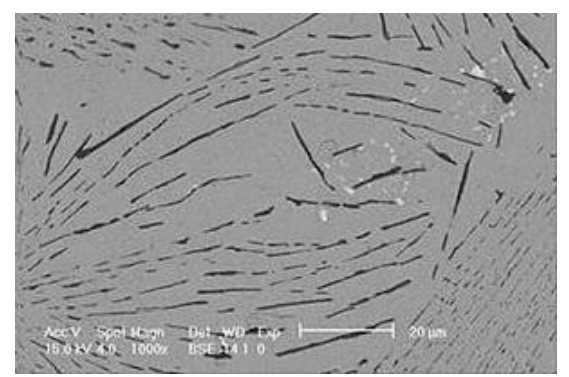

(a)

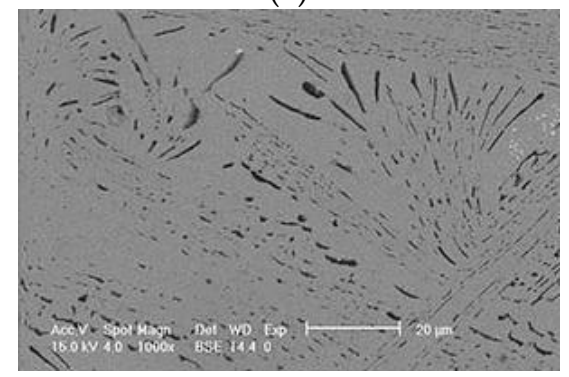

(c)

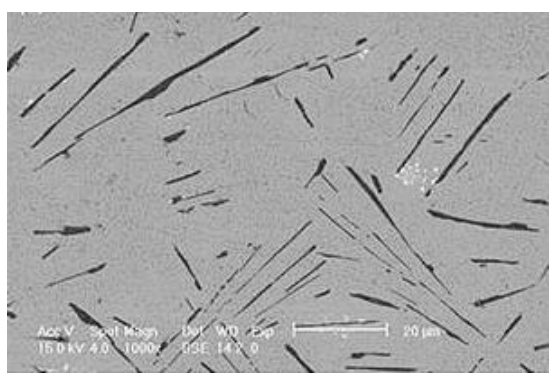

(b)

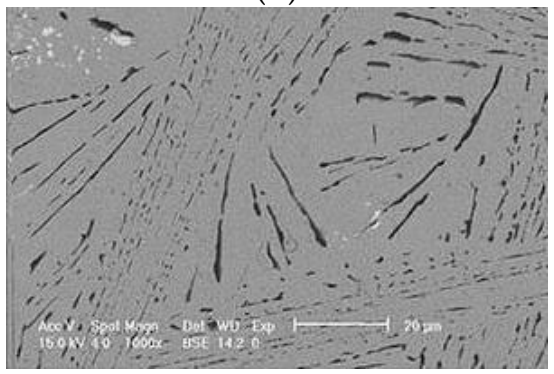

(d)

Figure 12. Microstructure of: (a) SnZnBi solders after being reflowed for $5 \mathrm{~min}$; (b) SnZnBi-0.5Ni composite solders after being reflowed for $30 \mathrm{~min}$; (c) SnZnBi solders after being reflowed for $30 \mathrm{~min}$; (d) SnZnBi-0.5Ni composite solders after being reflowed for $30 \mathrm{~min}$ [77].

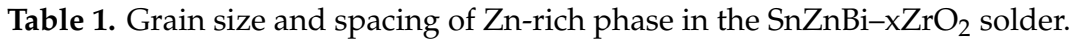

\begin{tabular}{ccccc}
\hline Solder & $\begin{array}{c}\text { Maximal Size } \\
(\mu \mathbf{m})\end{array}$ & $\begin{array}{c}\text { Minimal Size } \\
(\mu \mathbf{m})\end{array}$ & $\begin{array}{c}\text { Average } \\
\text { Size }(\mu \mathbf{m})\end{array}$ & $\begin{array}{c}\text { Average Spacing } \\
(\mu \mathbf{m})\end{array}$ \\
\hline SnZnBi & 10.5 & 1.2 & $4.6 \pm 0.09$ & $2.2 \pm 0.1$ \\
$\mathrm{SnZnBi}-0.25 \mathrm{ZrO}_{2}$ & 2.5 & 0.5 & $1.5 \pm 0.1$ & $1.3 \pm 0.04$ \\
$\mathrm{SnZnBi}-0.5 \mathrm{ZrO}_{2}$ & 6.6 & 0.4 & $2.8 \pm 0.3$ & $1.1 \pm 0.06$ \\
$\mathrm{SnZnBi}-1 \mathrm{ZrO}_{2}$ & 8.3 & 0.6 & $3.4 \pm 0.5$ & $2.1 \pm 0.08$ \\
\hline
\end{tabular}

\subsection{Mechanical Properties}

The addition of $1.0 \mathrm{wt} . \% \mathrm{Sb}$ nanoparticles greatly increased the tensile strength and decreased the elongation of the composite solder, as shown in Figure 13 [81]. The formation of $\varepsilon-\mathrm{Sb}_{3} \mathrm{Zn}_{4}$ not only reduced the amount of $\mathrm{Zn}$ atoms to form $\mathrm{Zn}$-rich phase, but also acted as nucleation sites, making the distribution of $\mathrm{Zn}$-rich phase more uniform. Thus, the tensile properties of the $\mathrm{SnZn}-\mathrm{nano} \mathrm{Sb}_{3} \mathrm{Zn}_{4}$ composite solder were improved. However, the microstructure of the solder matrix deteriorated when excessive $\mathrm{Sb}$ was added, resulting in the decrease of the tensile strength. It was reported that $\mathrm{Al}_{2} \mathrm{O}_{3}$ nanoparticles have a similar effect on the mechanical properties of SnZn solders [78].

Zhang et al. [82] found Ag nanoparticles could react with $\mathrm{Sn}$ atoms to form spherical-shaped $\mathrm{Ag}_{3} \mathrm{Sn}$ IMC phase, which refined the solder matrix and improved the mechanical properties. SnZn solder joints showed a typical brittle fracture, while SnZn-Ag solder joints presented dimple failure morphologies because of the refining effect of Ag nanoparticles. Due to the pinning effect and dispersion strengthening of $\mathrm{ZnO}$, the sliding of grain boundaries was retarded and the tensile creep properties of the composite were improved [80]. 


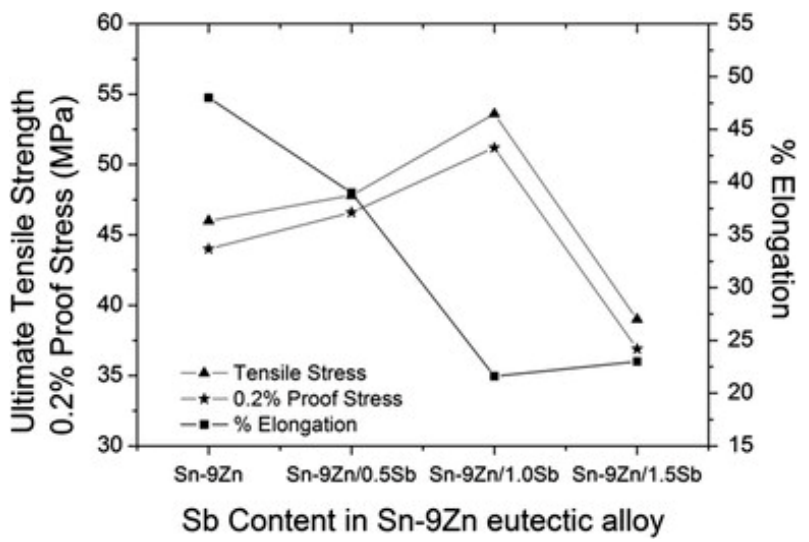

Figure 13. Effect of $\mathrm{Sb}$ nanoparticles on the tensile properties of the $\mathrm{Sn}-9 \mathrm{Zn}-\mathrm{xSb}$ composite solders $(x=0,0.5,1.0,1.5)[81]$.

In summary, Table 2 lists the mechanical properties of some lead-free solders bearing nanoparticles. As seen from the table, SnBi-based solders present higher strength and carbon nanomaterials (CNTs, GNSs) have great influence of the composite solders. In general, the addition of nanoparticles improves the tensile strength of the solders, but simultaneously reduces the elongation due to their strong restriction effect on the movements of dislocation. Therefore, the optimum content should be further determined by comprehensive comparison of mechanical properties and other performance such as wettability and reliability.

Table 2. The mechanical properties of nanoparticle-reinforced lead-free solders.

\begin{tabular}{|c|c|c|c|c|}
\hline Solders & UTS (MPa) & Elongation (\%) & Microhardness & References \\
\hline Sn3.0Ag0.5Cu & 46.0 & 29.5 & 1 & [83] \\
\hline $\mathrm{Sn} 0.3 \mathrm{Ag}-0.5 \mathrm{Cu} / 0.1 \mathrm{Mn}$ & 56.5 & / & / & [31] \\
\hline $\mathrm{Sn} 3.5 \mathrm{Ag} 0.25 \mathrm{Cu} / 1 \mathrm{TiO}_{2}$ & 70.1 & 25.2 & $18.5 \mathrm{HV}$ & [32] \\
\hline $\mathrm{Sn} 3.0 \mathrm{Ag} 0.5 \mathrm{Cu} / 0.05 \mathrm{La}_{2} \mathrm{O}_{3}$ & 79.0 & 14.1 & $13 \mathrm{HV}$ & [23] \\
\hline Sn3.0Ag0.5Cu/0.03GNSs & 50.3 & 23.5 & / & [83] \\
\hline $3 \mathrm{Sn} 3.0 \mathrm{Ag} 0.5 \mathrm{Cu} / 0.1 \mathrm{GNSs}$ & 50.7 & 21.5 & 1 & [83] \\
\hline Sn3.0Ag0.5Cu/0.2Ni-GNSs & 58.4 & / & $14.6 \mathrm{HV}$ & [84] \\
\hline Sn3.0Ag0.5Cu/0.05Ag-GNSs & 50.1 & 14.7 & / & [85] \\
\hline Sn $3.8 \mathrm{Ag} 0.7 \mathrm{Cu} / 1 \mathrm{CNTs}$ & 56.7 & 24.4 & / & [86] \\
\hline Sn58Bi & 81 & 21 & $0.30 \mathrm{GPa}$ & [63] \\
\hline Sn58Bi/0.01GNSs & 84 & 32 & $0.26 \mathrm{GPa}$ & [63] \\
\hline Sn58Bi/0.1GNSs & 93 & 17 & $0.41 \mathrm{GPa}$ & [63] \\
\hline Sn58Bi/0.03CNTs & 94.2 & 21.7 & / & {$[60]$} \\
\hline Sn9Zn & 41.0 & 43.4 & 13.6 BHN & [87] \\
\hline $\mathrm{Sn} 9 \mathrm{Zn} / 1.0 \mathrm{Ag}$ & 43.6 & 19.4 & $16 \mathrm{BHN}$ & [87] \\
\hline $\mathrm{Sn} 9 \mathrm{Zn} / 1.0 \mathrm{Sb}$ & 53.6 & 21.6 & $15.9 \mathrm{BHN}$ & [81] \\
\hline $\mathrm{Sn} 9 \mathrm{Zn} / 1.0 \mathrm{Al}_{2} \mathrm{O}_{3}$ & 43.4 & 44.9 & $27 \mathrm{HV}$ & [78] \\
\hline
\end{tabular}

\subsection{Wettability}

The SnZn solder has a poor wettability due to its poor oxidation resistance, which decreases the reliability of the solder joints. Figure 14 [88] shows that the addition of $\mathrm{ZrC}$ nanoparticles has a significant impact on the wettability of the SnZn solder. Compared with the plain SnZn solder, the spreading area of the $\mathrm{SnZn}-0.06 \mathrm{ZrC}$ composite solder could be increased from $143.64 \mathrm{~mm}^{2}$ to $190.92 \mathrm{~mm}^{2}$. However, when the content is excessive, $\mathrm{ZrC}$ nanoparticles would agglomerate at the surface of the molten solder, which inhibited the wetting and spreading of the liquid solder on Cu substrate. 


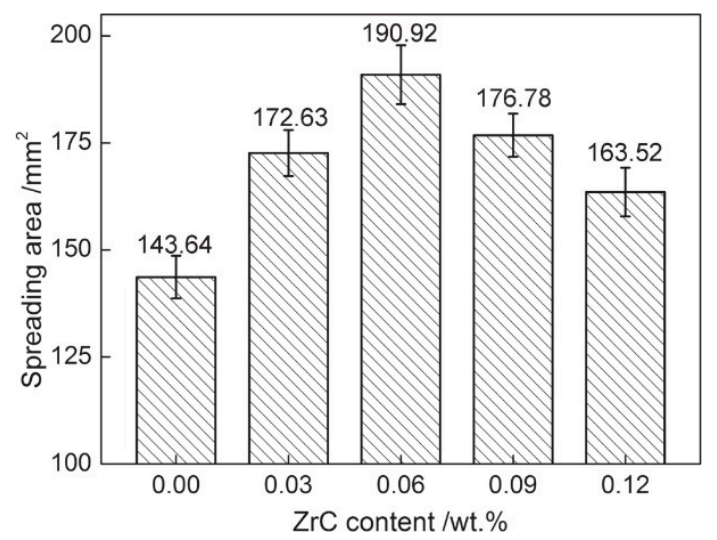

Figure 14. Spreading area of $\operatorname{SnZn}-x \mathrm{ZrC}(x=0,0.03,0.06,0.09,0.12)$ composite solders [88].

Generally, the larger the width of wetting ring is, the better wettability the solder has. Figure 15 illustrates that with the addition of $\mathrm{Al}_{2} \mathrm{O}_{3}$ nanoparticles, the spreading area and the width of precursor film increased [89]. Therefore, the wettability was improved by adding small amount of $\mathrm{Al}_{2} \mathrm{O}_{3}$ nanoparticles.

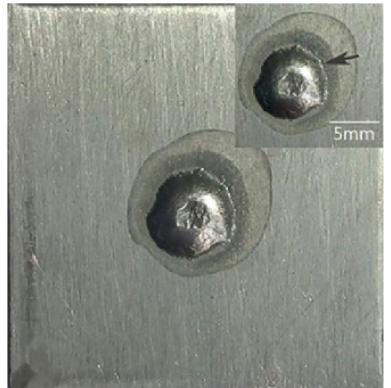

(a)

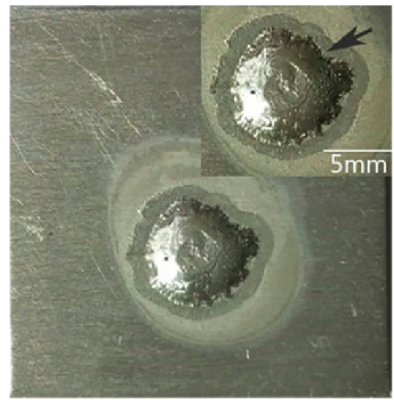

(b)

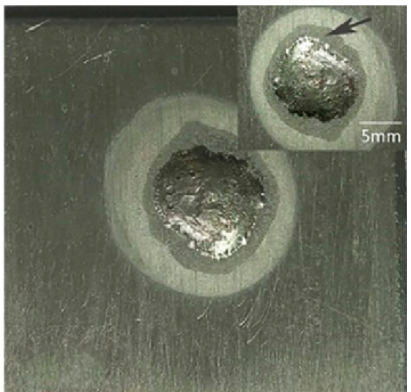

(c)

Figure 15. Macro morphology of $\mathrm{SnZn}-\mathrm{Al}_{2} \mathrm{O}_{3}$ composite solders after wetting on the 6061-aluminum alloy: (a) $0 \% \mathrm{Al}_{2} \mathrm{O}_{3}$; (b) $0.5 \% \mathrm{Al}_{2} \mathrm{O}_{3}$; (c) $1.0 \% \mathrm{Al}_{2} \mathrm{O}_{3}$ [89].

\subsection{Reliability}

During aging and reflow, the thickness of brittle $\mathrm{Cu}_{5} \mathrm{Zn}_{8}$ interfacial layer increases with time, which brings a great threat to the reliability of SnZn solders. Some research reported that RE addition could suppress the coarsening of $\mathrm{Cu}_{5} \mathrm{Zn}_{8} \mathrm{IMC}$, but it would also result in spontaneous growth of $\mathrm{Sn}$ whiskers and finally lead to the potential failure of electronics devices [90]. Research [91] shows that Ni nanoparticles can effectively increase the shear load of the solder joints due its grain refinement.

The practical use of SnZn solders is limited because the existence of $\mathrm{Zn}$-rich phase greatly reduces the oxidation resistance of the SnZn solder [92]. Under high temperature and humidity conditions, water vapor and oxygen oxidized both the surface microstructure and Zn-rich phase in the solder matrix, resulting in volume expansion and the increase of internal stress, which easily induces cracks along Sn grain boundaries. Chan et al. [91] found the addition of Ni nanoparticles could aid the formation of IMCs in the grain boundaries, so the penetration of $\mathrm{H}_{2} \mathrm{O}$ and $\mathrm{O}_{2}$ was inhibited as well as the formation of $\mathrm{ZnO}$. It is also reported that $\mathrm{Ag}$ nanoparticles increased the thermal and humidity stability of the SnZn-based solder alloy [76]. As shown in Figure 16, the oxidation of Zn-rich phase was significantly inhibited with the addition of $\mathrm{Ni}$ and $\mathrm{Ag}$ nanoparticles. 


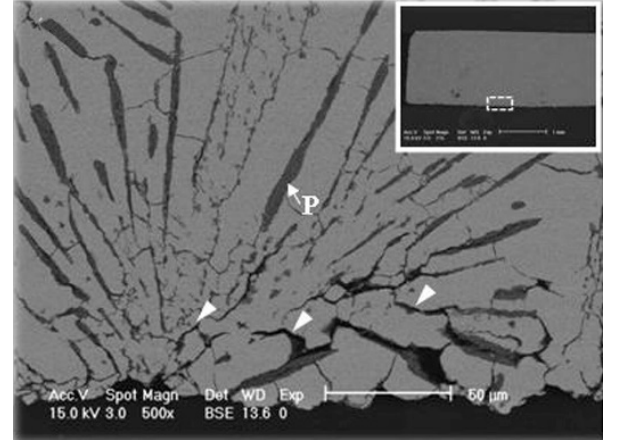

(a)

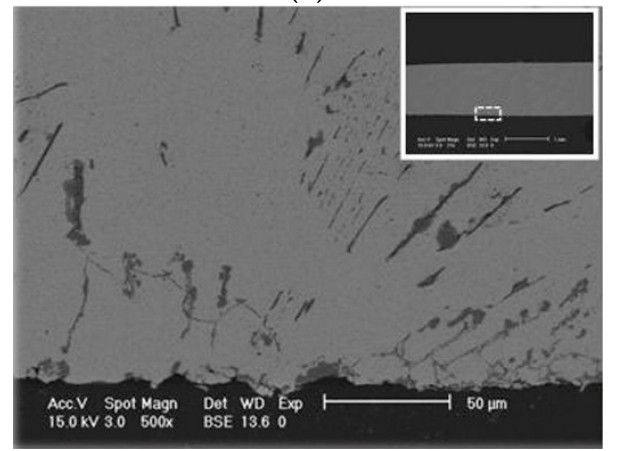

(c)

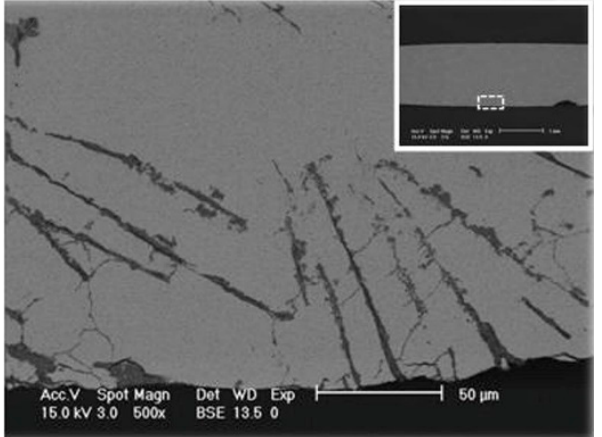

(b)

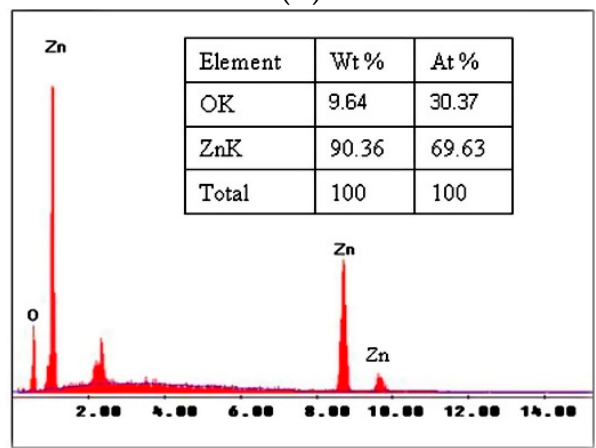

(d)

Figure 16. Microstructure of (a) SnZnBi, (b) SnZnBi-0.5Ag, and (c) SnZnBi-0.5Ni solder alloys at $85^{\circ} \mathrm{C} / 85 \%$ relative humidity $(\mathrm{RH})$ after exposure for $250 \mathrm{~h}$ and (d) energy dispersive spectrometer (EDS) analysis of region $\mathrm{P}$ in (a) [76].

\section{Conclusions}

Although lots of research results have been achieved in nanoparticle-reinforced lead-free solder, there are still several shortages existing in the application of the composite solder. Firstly, nanoparticle-reinforced lead-free solders remain in the experimental research stage and hardly replace the $\mathrm{SnPb}$ solder to meet the requirement of electronic package industries. Secondly, compared with microalloying, the amount of research on nanoparticle-reinforced lead-free solders is still relatively less and the influence mechanism of nanoparticles on the reliability of the composite solders in various service environments is insufficient. What is more, the preparation process of nanoparticle-reinforced composite solder is complex and the cost is high, which limits its industrial application. To further improve the properties of nanoparticle-reinforced lead-free solders, future development trends can be carried out in the following aspects:

1. With the development of electronic devices towards miniaturization and high performance, stricter requirements have been put forward for the reliability of lead-free solders. The current research mainly focuses on the effect of thermal stress and current stress on the performance of the solders. However, more and more electronic devices are applied to harsh environments such as cryogenic temperatures [93,94] and irradiation [95]. Therefore, research on the reliability of the solder bearing nanoparticles in these harsh environments will become a hot spot in this subject.

2. It has been proven that the coupling effects of RE and nanoparticles can further refine the microstructure and improve the mechanical properties of lead-free solders [96]. Thus, the combined addition of RE and nanoparticles may become a new reinforcement method to improve the performance of the solders.

3. Due to small tendency of agglomeration and fine physical and chemical properties, carbon-based nanomaterials can effectively improve the microstructure of lead-free solders and improve the 
properties $[97,98]$. Consequently, the development of new carbon-based nanomaterial-reinforced solders with better performance may become a new direction for the future research.

4. At present, lead-free solders bearing nanoparticles are mainly fabricated by mechanical mixing of the solder particles and nanoparticles. It is claimed that the nanoparticle-reinforced lead-free solders can also be directly prepared by adding nanoparticles though flux doping $[37,99]$ and in-situ formation [100]. Therefore, exploring new preparation methods with simpler processes and low cost attracts wide attention from researchers.

Author Contributions: S.X. conceived the idea; P.Z. and J.W. wrote the paper; P.X., S.Z., and W.L. advised the paper. All authors reviewed the paper.

Funding: This work was funded by the National Natural Science Foundation of China, grant No.51675269 and the Priority Academic Program Development of Jiangsu Higher Education Institutions (PAPD).

Conflicts of Interest: The authors declare no conflict of interest.

\section{References}

1. Seong Jun, K.; Coskun, K.; Taner, O.; Moonsub, S.; Ninad, P.; Alam, M.A.; Rotkin, S.V.; Rogers, J.A. High-performance electronics using dense, perfectly aligned arrays of single-walled carbon nanotubes. Nat. Nanotechnol. 2007, 2, 230-236.

2. Ramli, M.I.I.; Saud, N.; Salleh, M.A.A.M.; Derman, M.N.; Said, R.M. Effect of $\mathrm{TiO}_{2}$ additions on Sn-0.7Cu-0.05Ni lead-free composite solder. Microelectron. Reliab. 2016, 65, 255-264. [CrossRef]

3. Singh, A.K.; Panda, B.P.; Mohanty, S.; Nayak, S.K.; Gupta, M.K. Recent Developments on Epoxy-Based Thermally Conductive Adhesives (TCA): A Review. Polym. Plast. Technol. Eng. 2017, 57, 903-934. [CrossRef]

4. Li, Y.; Wong, C.P. Recent advances of conductive adhesives as a lead-free alternative in electronic packaging: Materials, processing, reliability and applications. Mater. Sci. Eng. R 2006, 51, 1-35. [CrossRef]

5. Shuang, L.; Xue, S.B.; Peng, X.; Luo, D.X. Present status of Sn-Zn lead-free solders bearing alloying elements. J. Mater. Sci. Mater. Electron. 2015, 26, 4389-4411.

6. Dudek, M.A.; Chawla, N. Effect of Rare-Earth (La, Ce, and Y) Additions on the Microstructure and Mechanical Behavior of Sn-3.9Ag-0.7Cu Solder Alloy. Metall. Mater. Trans. A 2010, 41, 610-620. [CrossRef]

7. Peng, X.; Xue, S.B.; Shen, Y.F.; Fei, L.; Hong, Z. Wettability and interfacial whiskers of Sn-9Zn-0.5Ga-0.08Nd solder with Sn, SnBi and Au/Ni coatings. J. Mater. Sci. Mater. Electron. 2014, 25, 3520-3525.

8. Chen, K.I.; Cheng, S.C.; Wu, S.; Lin, K.L. Effects of small additions of Ag, Al, and Ga on the structure and properties of the Sn-9Zn eutectic alloy. J. Alloy. Compd. 2006, 416, 98-105. [CrossRef]

9. Xu, C.; Feng, X.; Jian, Z.; Yao, Y. Effect of In on microstructure, thermodynamic characteristic and mechanical properties of $\mathrm{Sn-Bi}$ based lead-free solder. J. Alloy. Compd. 2015, 633, 377-383.

10. Gao, F.; Takemoto, T.; Nishikawa, H. Effects of Co and Ni addition on reactive diffusion between $\mathrm{Sn}-3.5 \mathrm{Ag}$ solder and Cu during soldering and annealing. Mater. Sci. Eng. A 2006, 420, 39-46. [CrossRef]

11. Tian, S.; Li, S.; Zhou, J.; Xue, F.; Cao, R.; Wang, F. Effect of indium addition on interfacial IMC growth and bending properties of eutectic Sn-0.7Cu solder joints. J. Mater. Sci. Mater. Electron. 2017, 28, 16120-16132. [CrossRef]

12. Xue, P.; Wang, K.H.; Zhou, Q.; Huang, J.; Long, W.M.; Zhang, Q.K. Effect of Nd on tin whisker growth in Sn-Zn soldered joint. J. Mater. Sci. Mater. Electron. 2016, 27, 3742-3747. [CrossRef]

13. Zhang, L.; Yang, F.; Zhong, S.-J. Whisker growth on SnAgCu-xPr solders in electronic packaging. J. Mater. Sci. Mater. Electron. 2016, 27, 5618-5621. [CrossRef]

14. Fawzy, A.; Fayek, S.A.; Sobhy, M.; Nassr, E.; Mousa, M.M.; Saad, G. Tensile creep characteristics of Sn-3.5Ag-0.5Cu (SAC355) solder reinforced with nano-metric ZnO particles. Mater. Sci. Eng. A 2014, 603, 1-10. [CrossRef]

15. Salleh, M.A.A.M.; Mcdonald, S.D.; Gourlay, C.M.; Yasuda, H.; Nogita, K. Suppression of $\mathrm{Cu}_{6} \mathrm{Sn}_{5}$ in $\mathrm{TiO}_{2}$ reinforced solder joints after multiple reflow cycles. Mater. Des. 2016, 108, 418-428. [CrossRef]

16. Yi, L.; Luo, K.; Lim, A.B.Y.; Zhong, C.; Wu, F.; Chan, Y.C. Improving the mechanical performance of Sn57.6Bi0.4Ag solder joints on $\mathrm{Au} / \mathrm{Ni} / \mathrm{Cu}$ pads during aging and electromigration through the addition of tungsten (W) nanoparticle reinforcement. Mater. Sci. Eng. A 2016, 669, 291-303.

17. Fathian, Z.; Maleki, A.; Niroumand, B. Synthesis and characterization of ceramic nanoparticles reinforced lead-free solder. Ceram. Int. 2017, 43, 5302-5310. [CrossRef] 
18. Zhang, L.; Tu, K.N. Structure and properties of lead-free solders bearing micro and nano particles. Mater. Sci. Eng. R 2014, 82, 1-32. [CrossRef]

19. Huang, Y.; Xiu, Z.; Wu, G.; Tian, Y.; He, P. Sn-3.0Ag-0.5Cu nanocomposite solders reinforced by graphene nanosheets. J. Mater. Sci. Mater. Electron. 2016, 27, 6809-6815. [CrossRef]

20. Zhu, Z.; Sun, H.; Wu, F.; Chan, Y.C. Comparative study of the microstructure and mechanical strength of tin-copper $(\mathrm{Sn} 0.7 \mathrm{Cu})$ solder modified with silver $(\mathrm{Ag})$ by both alloying and doping methods. J. Mater. Sci. Mater. Electron. 2016, 27, 1-10. [CrossRef]

21. Gain, A.K.; Chan, Y.C.; Yung, W.K.C. Effect of additions of $\mathrm{ZrO}_{2}$ nano-particles on the microstructure and shear strength of $\mathrm{Sn}-\mathrm{Ag}-\mathrm{Cu}$ solder on $\mathrm{Au} / \mathrm{Ni}$ metallized $\mathrm{Cu}$ pads. Microelectron. Reliab. 2011, 51, $2306-2313$. [CrossRef]

22. El-Daly, A.A.; Elmosalami, T.A.; Desoky, W.M.; El-Shaarawy, M.G.; Abdraboh, A.M. Tensile deformation behavior and melting property of nano-sized $\mathrm{ZnO}$ particles reinforced $\mathrm{Sn}-3.0 \mathrm{Ag}-0.5 \mathrm{Cu}$ lead-free solder. Mater. Sci. Eng. A 2014, 618, 389-397. [CrossRef]

23. Sharma, A.; Baek, B.G.; Jung, J.P. Influence of $\mathrm{La}_{2} \mathrm{O}_{3}$ nanoparticle additions on microstructure, wetting, and tensile characteristics of Sn-Ag-Cu alloy. Mater. Des. 2015, 87, 370-379. [CrossRef]

24. Ma, H.; Kunwar, A.; Liu, Z.; Chen, J.; Wang, Y.; Huang, M.; Zhao, N.; Ma, H. Shielding effect of Ag3Sn on growth of intermetallic compounds in isothermal heating and cooling during multiple reflows. J. Mater. Sci. Mater. Electron. 2018, 29, 4383-4390. [CrossRef]

25. Fouzder, T.; Shafiq, I.; Chan, Y.C.; Sharif, A.; Yung, W.K.C. Influence of $\mathrm{SrTiO}_{3}$ nano-particles on the microstructure and shear strength of $\mathrm{Sn}-\mathrm{Ag}-\mathrm{Cu}$ solder on $\mathrm{Au} / \mathrm{Ni}$ metallized $\mathrm{Cu}$ pads. J. Alloy. Compd. 2011, 509, 1885-1892. [CrossRef]

26. Chan, Y.H.; Arafat, M.M.; Haseeb, A.S.M.A. Effects of reflow on the interfacial characteristics between Zn nanoparticles containing Sn-3.8Ag-0.7Cu solder and copper substrate. Solder Surf. Mt. Tech. 2013, 25, 91-98. [CrossRef]

27. Tang, Y.; Luo, S.M.; Li, G.Y.; Yang, Z.; Hou, C.J. Ripening Growth Kinetics of Cu6Sn5 Grains in Sn-3.0Ag-0.5Cu-xTiO2/Cu Solder Joints During the Reflow Process. J. Electron. Packag. 2018, 140. [CrossRef]

28. Zhao, X.; Wen, Y.; Li, Y.; Liu, Y.; Wang, Y. Effect of $\gamma-\mathrm{Fe}_{2} \mathrm{O}_{3}$ nanoparticles size on the properties of Sn-1.0Ag-0.5Cu nano-composite solders and joints. J. Alloy. Compd. 2016, 662, 272-282. [CrossRef]

29. Zhu, Z.; Chan, Y.C.; Zhong, C.; Gan, C.L.; Wu, F. Effect of the size of carbon nanotubes (CNTs) on the microstructure and mechanical strength of CNTs-doped composite Sn0.3Ag0.7Cu-CNTs solder. Mater. Sci. Eng. A 2018, 727, 160-169. [CrossRef]

30. Lei, S.; Liang, Z.; Le, X.; Zhong, S.J.; Jia, M.; Li, B. Effect of nano-Al addition on properties and microstructure of low-Ag content Sn-1Ag-0.5Cu solders. J. Mater. Sci. Mater. Electron. 2016, 27, 7665-7673.

31. Tang, Y.; Luo, S.M.; Huang, W.F.; Pan, Y.C.; Li, G.Y. Effects of Mn nanoparticles on tensile properties of low-Ag Sn-0.3Ag-0.7Cu-xMn solder alloys and joints. J. Alloy. Compd. 2017, 719, 365-375. [CrossRef]

32. Tsao, L.C.; Chang, S.Y. Effects of $\mathrm{Nano}^{-\mathrm{TiO}_{2}}$ additions on thermal analysis, microstructure and tensile properties of Sn3.5Ag0.25Cu solder. Mater. Des. 2010, 31, 990-993. [CrossRef]

33. Zhang, L.; Han, J.; Liu, F.; Guo, Y.; He, C.; University, J.N. Effect of Nano-particles $\mathrm{TiO}_{2}$ on the Microstructures and Properties of SnAgCu Solders. Rare Metal Mat. Eng. 2013, 42, 1897-1900.

34. Jing, H.Y.; Guo, H.J.; Wang, L.X.; Wei, J.; Xu, L.Y.; Han, Y.D. Influence of Ag-modified graphene nanosheets addition into $\mathrm{Sn}-\mathrm{Ag}-\mathrm{Cu}$ solders on the formation and growth of intermetallic compound layers. J. Alloy. Compd. 2017, 702, 669-678. [CrossRef]

35. Du, C.H.; Li, Z.K.; Liu, B.; Li, C.T. The Frontier Analysis of RCS for Micro-Nano Particle. Adv. Mater. Res. 2011, 337, 526-531. [CrossRef]

36. Fu, G. Composite lead-free electronic solders. J. Mater. Sci. Mater. Electron. 2007, 18, 129-145.

37. Shen, J.; Chan, Y.C. Effect of metal/ceramic nanoparticle-doped fluxes on the wettability between $\mathrm{Sn}-\mathrm{Ag}-\mathrm{Cu}$ solder and a Cu layer. J. Alloy. Compd. 2009, 477, 909-914. [CrossRef]

38. Yue, G.; Zhao, X.; Yi, L.; Ying, L.; Yong, W.; Li, Z. Effect of nano-Fe ${ }_{2} \mathrm{O}_{3}$ additions on wettability and interfacial intermetallic growth of low-Ag content $\mathrm{Sn}-\mathrm{Ag}-\mathrm{Cu}$ solders on Cu substrates. J. Alloy. Compd. 2015, 627, 39-47.

39. Jie, W.; Xue, S.; Wang, J.; Wu, M.; Wang, J. Effects of $\alpha-\mathrm{Al}_{2} \mathrm{O}_{3}$ nanoparticles-doped on microstructure and properties of Sn-0.3Ag-0.7Cu low-Ag solder. J. Mater. Sci. Mater. Electron. 2018, 29, 7372-7387.

40. Sharma, A.; Sohn, H.-R.; Jung, J.P. Effect of Graphene Nanoplatelets on Wetting, Microstructure, and Tensile Characteristics of Sn-3.0Ag-0.5Cu (SAC) Alloy. Metall. Mater. Trans. A 2015, 47, 494-503. [CrossRef] 
41. Li, Y.; Ge, J.; Zhang, Y.; Dai, J. Interfacial IMC Layer and Tensile Properties of Ni-Reinforced $\mathrm{Cu} / \mathrm{Sn}-0.7 \mathrm{Cu}-0.05 \mathrm{Ni} / \mathrm{Cu}$ Solder Joint: Effect of Aging Temperature. Trans. Indian Inst. Met. 2017, 70, 2429-2439.

42. Tang, Y.; Li, G.Y.; Chen, D.Q.; Pan, Y.C. Influence of $\mathrm{TiO}_{2}$ nanoparticles on IMC growth in $\mathrm{Sn}-3.0 \mathrm{Ag}-0.5 \mathrm{Cu}-\mathrm{xTiO}{ }_{2}$ solder joints during isothermal aging process. J. Mater. Sci. Mater. Electron. 2014, 25, 981-991. [CrossRef]

43. Li, H.; An, R.; Wang, C. In situ quantitative study of microstructural evolution at the interface of Sn3.0Ag0.5Cu/Cu solder joint during solid state aging. J. Alloy. Compd. 2015, 634, 94-98. [CrossRef]

44. Chen, J.-S.; Wang, K.-Y.; Chen, J.-Q.; Yu, L. Suppression effect of $\mathrm{Cu}$ and Ag on $\mathrm{Cu}_{3} \mathrm{Sn}$ layer in solder joints. J. Mater. Sci. Mater. Electron. 2013, 24, 4630-4635.

45. Wen, Y.; Zhao, X.; Chen, Z.; Gu, Y.; Wang, Y.; Chen, Z.; Wang, X. Reliability enhancement of Sn-1.0Ag-0.5Cu nano-composite solders by adding multiple sizes of $\mathrm{TiO}_{2}$ nanoparticles. J. Alloy. Compd. 2017, 696, 799-807. [CrossRef]

46. Tsao, L.C. Suppressing effect of $0.5 \mathrm{wt} \%$ nano- $\mathrm{TiO}_{2}$ addition into Sn-3.5Ag-0.5Cu solder alloy on the intermetallic growth with $\mathrm{Cu}$ substrate during isothermal aging. J. Alloy. Compd. 2011, 509, 8441-8448. [CrossRef]

47. Chen, G.; Peng, H.; Silberschmidt, V.V.; Chan, Y.C.; Liu, C.; Wu, F. Performance of Sn-3.0Ag-0.5Cu composite solder with TiC reinforcement: Physical properties, solderability and microstructural evolution under isothermal ageing. J. Alloy. Compd. 2016, 685, 680-689. [CrossRef]

48. Huang, M.; Zhang, Z.; Zhou, S.; Chen, L. Stress relaxation and failure behavior of Sn-3.0Ag-0.5Cu flip-chip solder bumps undergoing electromigration. J. Mater. Res. 2014, 29, 2556-2564. [CrossRef]

49. An, R.; Tian, Y.; Zhang, R.; Wang, C. Electromigration-induced intermetallic growth and voids formation in symmetrical $\mathrm{Cu} / \mathrm{Sn} / \mathrm{Cu}$ and $\mathrm{Cu} / \mathrm{Intermetallic} \mathrm{compounds} \mathrm{(IMCs)/Cu} \mathrm{joints.} \mathrm{J.} \mathrm{Mater.} \mathrm{Sci.} \mathrm{Mater.} \mathrm{Electron.}$ 2015, 26, 2674-2681. [CrossRef]

50. Sharma, A.; Di, E.X.; Chow, J.; Mayer, M.; Sohn, H.R.; Jung, J.P. Electromigration of composite Sn-Ag-Cu solder bumps. Electron. Mater. Lett. 2015, 11, 1072-1077. [CrossRef]

51. Yang, Z.; Wei, Z.; Ping, W.U. Effects of Ni-coated Carbon Nanotubes addition on the electromigration of Sn-Ag-Cu solder joints. J. Alloy. Compd. 2013, 581, 202-205. [CrossRef]

52. Sha, X.U.; Yan, C.C.; Zhang, K.; Yung, K.C. Interfacial intermetallic growth and mechanical properties of carbon nanotubes reinforced Sn3.5Ag0.5Cu solder joint under current stressing. J. Alloy. Compd. 2014, 595, 92-102.

53. Bui, Q.V.; Nam, N.D.; Noh, B.I.; Kar, A.; Kim, J.G.; Jung, S.B. Effect of Ag addition on the corrosion properties of Sn-based solder alloys. Mater. Corros. 2015, 61, 30-33. [CrossRef]

54. Xu, L.Y.; Zhang, Z.K.; Jing, H.Y.; Wei, J.; Han, Y.D. Effect of graphene nanosheets on the corrosion behavior of Sn-Ag-Cu solders. J. Mater. Sci. Mater. Electron. 2015, 26, 5625-5634. [CrossRef]

55. Gain, A.K.; Zhang, L. Interfacial microstructure, wettability and material properties of nickel (Ni) nanoparticle doped tin-bismuth-silver (Sn-Bi-Ag) solder on copper (Cu) substrate. J. Mater. Sci. Mater. Electron. 2016, 27, 1-13. [CrossRef]

56. Sun, H.; Li, Q.; Chan, Y.C. A study of Ag additive methods by comparing mechanical properties between Sn57.6Bi0.4Ag and $0.4 \mathrm{wt} \%$ nano-Ag-doped Sn58Bi BGA solder joints. J. Mater. Sci. Mater. Electron. 2014, 25, 4380-4390. [CrossRef]

57. Yi, L.; Chan, Y.C. Effect of silver (Ag) nanoparticle size on the microstructure and mechanical properties of Sn58Bi-Ag composite solders. J. Alloy. Compd. 2015, 645, 566-576.

58. Yang, L.; Hao, Z.; Sun, F. Solderability of SnBi-nano Cu solder pastes and microstructure of the solder joints. J. Mater. Sci. Mater. Electron. 2016, 27, 2235-2241.

59. Li, X.; Yong, M.; Wei, Z.; Ping, W. Effects of nanoscale $\mathrm{Cu}_{6} \mathrm{Sn}_{5}$ particles addition on microstructure and properties of SnBi solder alloys. Mater. Sci. Eng. A 2017, 684, 328-334. [CrossRef]

60. Peng, H.E.; Xiao-Chun, L.; Lin, T.S.; Hai-Xin, L.I.; Jing, A.N.; Xin, M.A.; Feng, J.C.; Yan, Z.; Qi, L.I.; Qian, Y.Y. Improvement of mechanical properties of $\mathrm{Sn}-58 \mathrm{Bi}$ alloy with multi-walled carbon nanotubes. T. Nonferr. Metal. Soc. 2012, 22, s692-s696.

61. Sun, H.; Chan, Y.C.; Wu, F. Effect of CNTs and Ni coated CNTs on the mechanical performance of Sn57.6Bi0.4Ag BGA solder joints. Mater. Sci. Eng. A 2016, 656, 249-255. [CrossRef]

62. Yang, L.; Wei, Z.; Liang, Y.; Cui, W.; Ping, W. Improved microstructure and mechanical properties for Sn58Bi solder alloy by addition of Ni-coated carbon nanotubes. Mater. Sci. Eng. A 2015, 642, 7-15. [CrossRef] 
63. Ma, Y.; Li, X.; Zhou, W.; Yang, L.; Wu, P. Reinforcement of graphene nanosheets on the microstructure and properties of Sn58Bi lead-free solder. Mater. Des. 2017, 113, 264-272. [CrossRef]

64. Ma, D.; Wu, P. Improved microstructure and mechanical properties for Sn58Bi0.7Zn solder joint by addition of graphene nanosheets. J. Alloy. Compd. 2016, 671, 127-136. [CrossRef]

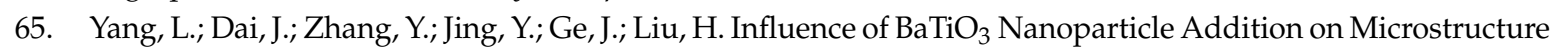
and Mechanical Properties of Sn-58Bi Solder. J. Electron. Mater. 2015, 44, 2473-2478. [CrossRef]

66. Liu, X.; Huang, M.; Wu, C.M.L.; Lai, W. Effect of $\mathrm{Y}_{2} \mathrm{O}_{3}$ particles on microstructure formation and shear properties of Sn-58Bi solder. J. Mater. Sci. Mater. Electron. 2010, 21, 1046-1054. [CrossRef]

67. Zhang, H.; Liu, Y.; Sun, F.; Ban, G.; Fan, J. Effects of nano-copper particles on the properties of Sn58Bi composite solder pastes. Microelectron. Int. 2017, 34, 40-44. [CrossRef]

68. Wang, F.; Chen, H.; Huang, Y.; Liu, L.; Zhang, Z. Recent progress on the development of Sn-Bi based low-temperature Pb-free solders. J. Mater. Sci. Mater. Electron. 2019, 30, 3222-3243. [CrossRef]

69. Yang, Q.L.; Shang, J.K. Interfacial segregation of Bi during current stressing of Sn-Bi/Cu solder interconnect. J. Electron. Mater. 2005, 34, 1363-1367. [CrossRef]

70. Gu, X.; Yang, D.; Chan, Y.C.; Wu, B.Y. Effects of electromigration on the growth of intermetallic compounds in $\mathrm{Cu} / \mathrm{SnBi} / \mathrm{Cu}$ solder joints. J. Mater. Res. 2008, 23, 2591-2596. [CrossRef]

71. Ismathullakhan, S.; Lau, H.; Chan, Y.C. Enhanced electromigration reliability via Ag nanoparticles modified eutectic Sn-58Bi solder joint. Microsyst. Technol. 2013, 19, 1069-1080. [CrossRef]

72. $\mathrm{Hu}, \mathrm{T}$; $\mathrm{Yi}$, L.; Chan, Y.C.; Wu, F. Effect of nano $\mathrm{Al}_{2} \mathrm{O}_{3}$ particles doping on electromigration and mechanical properties of Sn-58Bi solder joints. Microelectron. Reliab. 2015, 55, 1226-1233. [CrossRef]

73. Li, L.F.; Cheng, Y.K.; Xu, G.L.; Wang, E.Z.; Zhang, Z.H.; Wang, H. Effects of indium addition on properties and wettability of Sn-0.7Cu-0.2Ni lead-free solders. Mater. Des. 2014, 64, 15-20. [CrossRef]

74. Liang, Z.; Junhua, C.; Jiguang, H.; Yonghuan, G.; Chengwen, H.E. Microstructures and properties of SnZn-xEr lead-free solders. J. Rare Earth. 2012, 30, 790-793.

75. Peng, X.; Xue, S.B.; Shen, Y.F.; Hong, Z. Interfacial microstructures and mechanical properties of Sn-9Zn-0.5Ga-xNd on Cu substrate with aging treatment. Mater. Des. 2014, 60, 1-6.

76. Gain, A.K.; Zhang, L. Microstructure, thermal analysis and damping properties of Ag and Ni nano-particles doped Sn-8Zn-3Bi solder on OSP-Cu substrate. J. Alloy. Compd. 2014, 617, 779-786. [CrossRef]

77. Fouzder, T.; Li, Q.; Chan, Y.C.; Chan, D.K. Microstructure and kinetic analysis of the properties and behavior of nickel (Ni) nano-particle doped tin-zinc-bismuth ( $\mathrm{Sn}-8 \mathrm{Zn}-3 \mathrm{Bi}$ ) solders on immersion silver (Ag)-plated copper (Cu) substrates. J. Mater. Sci. Mater. Electron. 2014, 25, 2529-2539. [CrossRef]

78. Xing, W.Q.; Yu, X.Y.; Li, H.; Le, M.; Wei, Z.; Peng, D.; Wang, W.X.; Min, D. Microstructure and mechanical properties of $\mathrm{Sn}-9 \mathrm{Zn}-\mathrm{xAl}{ }_{2} \mathrm{O}_{3}$ nanoparticles $(\mathrm{x}=0-1)$ lead-free solder alloy: first-principles calculation and experimental research. Mater. Sci. Eng. A 2016, 678, 252-259. [CrossRef]

79. Peng, C.; Shen, J.; Yin, H. Influences of $\mathrm{ZrO}_{2}$ nano-particles on the microstructures and microhardness of Sn8Zn1Bi-xZrO $2 / C u$ solder joints. J. Mater. Sci. Mater. Electron. 2013, 24, 203-210. [CrossRef]

80. Al-Ganainy, G.S.; El-Daly, A.A.; Fawzy, A.; Hussein, N. Effect of adding nanometric ZnO particles on thermal, microstructure and tensile creep properties of $\mathrm{Sn}-6.5 \mathrm{wt} \% \mathrm{Zn}-3 \mathrm{wt} \%$ In solder alloy. J. Mater. Sci. Mater. Electron. 2017, 28, 13303-13312. [CrossRef]

81. Shafiq, I.; Chan, Y.C.; Yung, W.K.C. Influence of small Sb nanoparticles additions on the microstructure, hardness and tensile properties of Sn-9Zn binary eutectic solder alloy. J. Mater. Sci. Mater. Electron. 2012, 23, 1427-1434. [CrossRef]

82. Gain, A.K.; Chan, Y.C.; Sharif, A.; Wong, N.B.; Yung, W.K.C. Interfacial microstructure and shear strength of Ag nano particle doped Sn-9Zn solder in ball grid array packages. Microelectron. Reliab. 2009, 49, 746-753. [CrossRef]

83. Liu, X.D.; Han, Y.D.; Jing, H.Y.; Wei, J.; Xu, L.Y. Effect of graphene nanosheets reinforcement on the performance of Sn-Ag-Cu lead-free solder. Mater. Sci. Eng. A 2013, 562, 25-32. [CrossRef]

84. Chen, G.; Wu, F.; Liu, C.; Silberschmidt, V.V.; Chan, Y.C. Microstructures and properties of new $\mathrm{Sn}-\mathrm{Ag}-\mathrm{Cu}$ lead-free solder reinforced with Ni-coated graphene nanosheets. J. Alloy. Compd. 2016, 656, 500-509. [CrossRef]

85. Xu, L.; Chen, X.; Jing, H.; Wang, L.; Wei, J.; Han, Y. Design and performance of Ag nanoparticle-modified graphene/SnAgCu lead-free solders. Mater. Sci. Eng. A 2016, 667, 87-96. [CrossRef] 
86. Kumar, K.M.; Kripesh, V.; Tay, A.A.O. Single-wall carbon nanotube (SWCNT) functionalized Sn-Ag-Cu lead-free composite solders. J. Alloy. Compd. 2008, 450, 229-237. [CrossRef]

87. Ahmed, M.; Fouzder, T.; Sharif, A.; Gain, A.K.; Chan, Y.C. Influence of Ag micro-particle additions on the microstructure, hardness and tensile properties of $\mathrm{Sn}-9 \mathrm{Zn}$ binary eutectic solder alloy. Microelectron. Reliab. 2010, 50, 1134-1141. [CrossRef]

88. Li, Y.; Song, B.; Zhang, Y.; Xiong, Y.; Shi, X.; Zhang, K. Microstructure, interfacial IMC layer and mechanical properties of $\mathrm{Cu} / \mathrm{Sn}-9 \mathrm{Zn}-\mathrm{xZrC} / \mathrm{Cu}$ solder joints. Mater. Res. Express 2018, 5. [CrossRef]

89. Xing, W.-Q.; Yu, X.-Y.; Li, H.; Ma, L.; Zuo, W.; Dong, P.; Wang, W.-X.; Ding, M. Effect of nano $\mathrm{Al}_{2} \mathrm{O}_{3}$ additions on the interfacial behavior and mechanical properties of eutectic $\mathrm{Sn}-9 \mathrm{Zn}$ solder on low temperature wetting and soldering of 6061 aluminum alloys. J. Alloy. Compd. 2017, 695, 574-582. [CrossRef]

90. Xue, P.; Xue, S.-B.; Shen, Y.-F.; Zhu, H. Inhibiting the growth of Sn whisker in Sn-9Zn lead-free solder by Nd and Ga. J. Mater. Sci. Mater. Electron. 2014, 25, 2671-2675. [CrossRef]

91. Gain, A.K.; Chan, Y.C.; Yung, W.K.C. Effect of nano Ni additions on the structure and properties of Sn-9Zn and $\mathrm{Sn}-\mathrm{Zn}-3 \mathrm{Bi}$ solders in Au/Ni/Cu ball grid array packages. Mater. Sci. Eng. B 2009, 162, 92-98. [CrossRef]

92. Lee, J.E.; Kim, K.S.; Inoue, M.; Jiang, J.; Suganuma, K. Effects of Ag and Cu addition on microstructural properties and oxidation resistance of Sn-Zn eutectic alloy. J. Alloy. Compd. 2008, 454, 310-320. [CrossRef]

93. Tian, R.; Tian, Y.; Wang, C.; Zhao, L. Mechanical properties and fracture mechanisms of Sn-3.0Ag-0.5Cu solder alloys and joints at cryogenic temperatures. Mater. Sci. Eng. A 2017, 684, 697-705. [CrossRef]

94. Yao, Y.; Li, X.; He, X. Effect of deep cryogenic treatment on mechanical properties and microstructure of Sn3.0Ag0.5Cu solder. J. Mater. Sci. Mater. Electron. 2018, 29, 4517-4525. [CrossRef]

95. Wang, J.; Xue, S.; Lv, Z.; Wang, L.; Liu, H.; Wen, L. Effect of gamma-ray irradiation on microstructure and mechanical property of Sn63Pb37 solder joints. J. Mater. Sci. Mater. Electron. 2018, 29, 20726-20733. [CrossRef]

96. Wu, J.; Xue, S.; Wang, J.; Wu, M. Coupling effects of rare-earth $\mathrm{Pr}$ and $\mathrm{Al}_{2} \mathrm{O}_{3}$ nanoparticles on the microstructure and properties of Sn-0.3Ag-0.7Cu low-Ag solder. J. Alloy. Compd. 2019, 784, 471-487. [CrossRef]

97. Chen, G.; Li, L.; Du, J.; Silberschmidt, V.V.; Chan, Y.C.; Liu, C.; Wu, F. Thermo-migration behavior of SAC305 lead-free solder reinforced with fullerene nanoparticles. J. Mater. Sci. 2016, 51, 10077-10091. [CrossRef]

98. Khodabakhshi, F.; Sayyadi, R.; Javid, N.S. Lead free Sn-Ag-Cu solders reinforced by Ni-coated graphene nanosheets prepared by mechanical alloying: Microstructural evolution and mechanical durability. Mater. Sci. Eng. A 2017, 702, 371-385. [CrossRef]

99. Bashir, M.N.; Haseeb, A.S.M.A.; Rahman, A.Z.M.S.; Fazal, M.A.; Kao, C.R. Reduction of electromigration damage in SAC305 solder joints by adding Ni nanoparticles through flux doping. J. Mater. Sci. 2015, 50, 6748-6756. [CrossRef]

100. Shen, J.; Liu, Y.C.; Gao, H.X. In situ nanoparticulate-reinforced lead-free Sn-Ag composite prepared by rapid solidification. J. Mater. Sci. Mater. Electron. 2006, 18, 463-468. [CrossRef]

(C) 2019 by the authors. Licensee MDPI, Basel, Switzerland. This article is an open access article distributed under the terms and conditions of the Creative Commons Attribution (CC BY) license (http://creativecommons.org/licenses/by/4.0/). 